\title{
INVESTIGATION OF FOUNDATION PROBLEMS RELATED TO HEAVING OF SOILS AND WEATHERED BEDROCK IN THE PIERRE SHALE SOUTHWEST OF DENVER, COLORADO
}

\author{
Thomas C. Nichols, Jr. ${ }^{1}$
}

\author{
With sections on Clay Mineralogy by D.D. Eber ${ }^{2}$ and \\ Seismic-Reflection Data Interpretation by R.A. Williams ${ }^{1}$ and K.W. King ${ }^{1}$
}

Open-File Report 91-281

This report is preliminary and has not been reviewed for conformity with U.S. Geological Survey editorial standards. Any use of trade, product, or firm names is for descriptive purposes only and does not imply endorsement by the U.S. Government.
${ }^{1}$ Golden, Colo.
${ }^{2}$ Denver, Colo. 


\section{CONTENTS}

\section{Page}

Abstract . . . . . . . . . . . . . . . . .

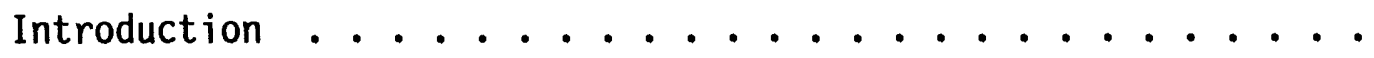

Acknowledgments ..................... 6

Field investigations .............................. 6

Determination of physical properties .......... 12

Evidence for rebound . . . . . . . . . . . . . 12

Seismic-data interpretation ................... 15

Conclusions ..................................... 16

Recommendations ......................... 17

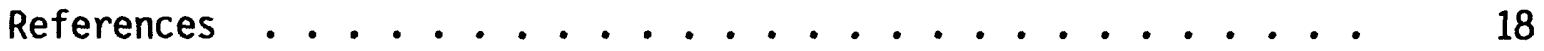

Appendix A ............................. 19

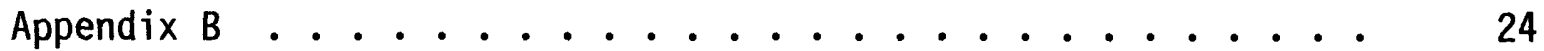

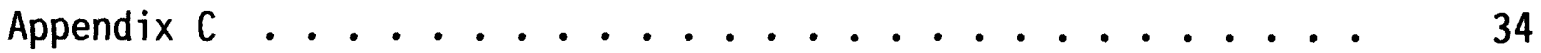




\title{
Investigation of foundation problems related to heaving of soils and weathered bedrock in the Pierre Shale southwest of Denver, Colorado
}

\author{
by Thomas C. Nichols, Jr.
}

\begin{abstract}
Within the area of outcropping Pierre Shale southwest of greater Denver, Colo., numerous dwelling and highway foundations have suffered mild to major damage caused by heaving soils and bedrock. An investigation was conducted to assess the possible relative contribution of bedrock rebound to the excessive amount of structural damage in the area. Rebound in the shale consists primarily of volume expansion (increase of void volume) that results when clay bonds are weakened by weathering or deformational events allowing the release of recoverable strain energy that is stored from diagenetic processes or results from swelling caused by hydration of clays. Using trench and borehole samples at a common location adjacent to the damage area, a geologic and physical-properties profile was developed for a section of the shale undisturbed by engineering practice. High-resolution seismic reflection and refraction techniques were used to further project the geologic information. The profile reflects the natural rebound that has taken place in the shale section as a result of natural erosional unloading. In addition, the profile reflects potential rebound that can take place as a result of future unloading caused by engineering excavation or erosion. The unweathered shale at $27-m$ depth has rebounded very little, if any, but in comparison, all shallower weathered samples have expanded, some to as much as 20 percent near the surface of the shale where maximum expansion has taken place. Fractured and faulted zones observed in the profile greatly influenced the rebound volumes apparently by causing further weakening of the clay bonds and allowing excess expansion to occur. In these zones, excess rebound is limited by the horizontal constraint.

Even though the moisture content increases upward in the weathered section of the shale, the degree of saturation decreases. The unweathered shale at 27-m depth is totally saturated, but saturation decreases toward the surface to as little as 86 percent. Even in a highly fractured zone with abundant ground water, the shale is only 92 percent saturated. The measured saturations imply that the void-volume changes become only slightly to partially filled with available pore water and take place prior to pore-water transfer into new void space and that the degree of saturation of the clays is decreasing. In addition, a profile of the clay mineralogy shows that perceptible changes of exchangeable cations that stabilize the swelling clays take place in the weathered zone. These conditions further suggest the possibility that the rebound volume change may or may not be related to swelling of the clays by hydration.
\end{abstract}


Rebound of geological materials is attributed to stress relief, but the process is poorly understood and the basis for predicting time-dependent rebound displacements has not been clearly established. Not only are changes of stress important to the rebound process, but so are fabric, physical properties, mineralogy, and anisotropy of the geologic materials, and external environmental influences such as moisture and temperature (Nichols, 1980). The problem of rebound is one with which engineers must deal whenever the equilibrium of geological materials is disturbed, especially in large excavations. In areas where rebound deformations can significantly affect engineering structures, it is desirable to understand rebound behavior and to determine practical guidelines for prediction of the short- and long-term consequences of rebound. This report deals with the rebound (as defined above) of the Pierre Shale.

The natural rebound profile infers that a large part of the rebound has occurred in a time-dependent manner in the top 2-4 $\mathrm{m}$ of the shale. Future excavations removing existing surficial or bedrock loads would substantially disturb the natural rebound profile and allow further rebound expansion to occur. The expansion displacements are likely to be time-dependent and sufficiently large to cause major foundation damage to overlying structures. Along zones of geologic structural discontinuities or highly fractured bedrock disturbed by engineering excavations, new structures may be especially susceptible to damage caused by rebound displacements.

Recommendations are made to study the rebound process with pre- and postexcavation investigations by observing changes that take place in the physical properties, mineralogy, and geologic features of the shale profiles and relating these to measured displacements that occur during and after engineering construction.

\section{INTRODUCTION}

Outcropping Pierre Shale along the western and southwestern perimeter of the greater Denver, Colo., metropolitan area is the source of severe foundation problems and road damage in recently developed communities and highways. Much of the damage is caused by swelling clay soils and heaving bedrock (rebound) produced by the weathering and erosion processes in the Pierre Shale (generally a smectitic clay shale in this area). In the area of concern, Pierre Shale beds approximately $2.1 \mathrm{~km}$ thick dip steeply eastward (greater than $45^{\circ}$ ) as a result of regional uplift and, except where locally covered by alluvial deposits, crop out for at least $2.4 \mathrm{~km}$ in an easterly direction and for many kilometers along a southerly strike direction.

Less is known about the rebound behavior of clay shale bedrock than the behavior of the overlying derived clay soils, both of which are likely to cause severe damage to engineered structures. Consequently, there is a need 
to establish a better understanding of rebound processes in the area so that engineering practice needed to mitigate rebound deformations can be substantially improved.

Because there may be more than one understanding of rebound among practitioners dealing with the problem of heaving and swelling soils, it is defined here to be the expansive recovery of surficial crustal material, either instantaneous or time dependent, or both, which is initiated by the removal or relaxation of superincumbent loads (Nichols, 1980). The displacements caused by rebound allow elastic and inelastic relaxation of the crustal masses to occur. The outward and upward movements associated with rebound are uplift displacements related to rebound processes.

Rebound displacements consisting of instantaneous elastic and timedependent anelastic components commonly occur in shales that have become overconsolidated by natural processes and are subsequently rapidly unloaded by natural or engineering excavations. Often, these displacements are not anticipated and, therefore, not considered in initial design criteria.

During the construction of the Oahe Dam, on the Missouri River $16 \mathrm{~km}$ northwest of Pierre, South Dakota, the U.S. Army Corps of Engineers encountered time-dependent vertical ground offsets up to $0.3 \mathrm{~m}$ in the Pierre Shale. Approximately a month after massive excavations for the dam stilling basin were finished (Underwood and others, 1964), abrupt rebound displacements along pre-existing, steeply dipping fault planes on the floor of the basin were detected over a period of 3 days. These were followed by time-dependent displacements that were measured for a year. The U.S. Army Corps of Engineers successfully modified the design of the dam to compensate for any future rebound deformations. The foundation investigations carried out by Underwood and others (1964), and nearby geologic investigations conducted in the Pierre Shale by the U.S. Geological Survey (Nichols and others, 1986; Collins and others, 1988) indicate that continuing differential rebound displacements are significantly influenced by pre-existing fault planes. Engineering design needed to mitigate time-dependent rebound damage to highways recently constructed over pre-existing faults in the Pierre Shale of South Dakota has not been completely successful.

During and after the construction of Interstate 5 through Seattle, Wash., slope instability resulting from horizontal rebound deformations was a major problem (Strazer and others, 1974). After slopes were excavated, timedependent movement along deep-seated, nearly horizontal slip surfaces occurred within the Lawton Clay, a proglacial, varved lake deposit. Resulting failures in retaining walls and cut slopes required substantial redesign of the highway. Similarly, horizontal failures in the Pierre Shale of South Dakota that may contribute to slope instability have been explained by rebound deformations caused by erosional unloading of the shale (Nichols and others, 1986). 
Within the area of outcropping Pierre Shale southwest of greater Denver, new subdivisions have been built since the early 1970s in an area (fig. 1) bounded by Quincy Avenue on the north, Interstate C470 on the west, Simms Avenue on the east, and Belleview Avenue on the south that have had a history of continuing excessive damage to foundations, roadways, and utility lines. Kline (1982) conducted a multivariate analys is of independent construction conditions in this area that may have contributed to the prediction of foundation damage, the dependent variable. The independent variables were house style, foundation type, depth to bedrock, soil type, and age. He concluded that only the age of the house and the depth to bedrock were significant in predicting house damage. Both of these construction variables, simultaneously influencing foundation damage, may imply that time-dependent deformations caused by the disturbance of the shale during construction are a result of rebound. The removal of overlying surficial or weathered shale deposits causes significant rebound deformations. In addition, a major regional geologic structure, the Golden fault, extends into the area of severe damage (Kline, 1982, and fig. 1, plate V). There is good evidence that tectonic fault displacements on this structure may have occurred as recently as Quaternary time (Kirkham and Rogers, 1981). However, an examination of areal photographs taken in 1937, 1949, 1964, 1971, and 1972 shows no geomorphic evidence of recent movement along the fault trace. Nonetheless, past disturbance of the clay matrix within the shale (bedrock fracturing) along the Golden fault may be a significant feature contributing to differential rebound displacements upon excavation of the surrounding shale.

This report presents data and conclusions of a preliminary study conducted to assess the rebound process and the contribution of rebound deformations to the severe damage of dwelling foundations and local roadways in the recently developed community at the selected location.

\section{ACKNOWLEDGMENTS}

H.S. Swolfs and D.S. Collins of the U.S. Geological Survey provided expert help in sampling the trench and drill-hole cores and in making the on-site determinations of moisture content and bulk density.

\section{FIELD INVESTIGATIONS}

To evaluate possible destructive rebound deformations and their severity, a single site of investigation was chosen adjacent to an area with a known high-density occurrence of engineering structural damage (KIine, 1982). The site location ( $p l a t e ~ 1)$ was chosen as close as feasible to the inferred location of the Golden fault (Scott, 1972) on terrain undisturbed by construction activity and yet with as little thickness of surficial deposits overlying the Pierre Shale as possible. The near-surface geology was mapped, 


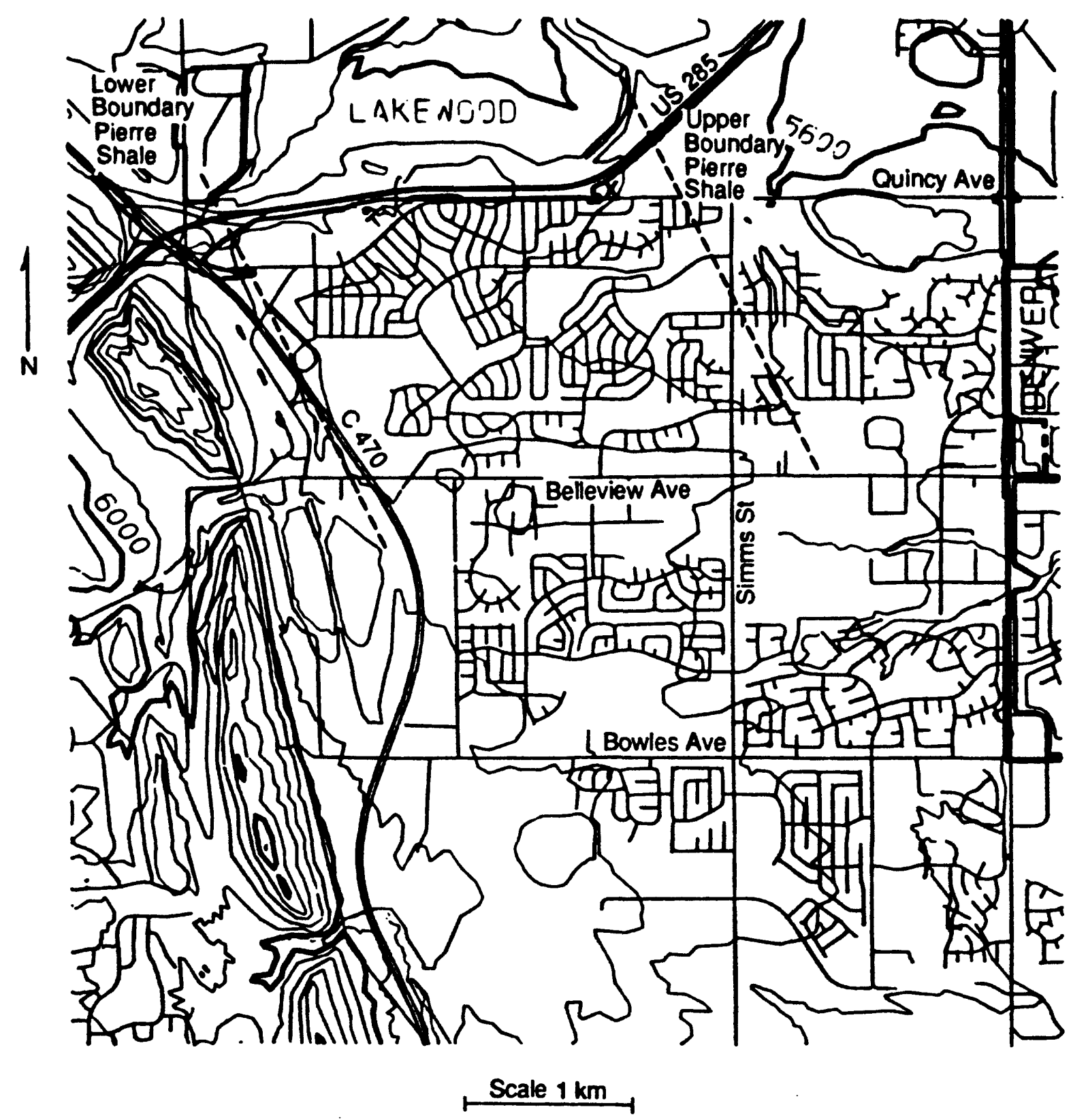

FIGURE 1.--Map showing area of damaged homes, Quincy Avenue on north, Simms Street on east, Belleview Avenue on south, and Colorado State Highway $\mathrm{C} 470$ on west. Upper and lower boundaries of outcropping Pierre Shale in the area also are approximately located (after Scott, 1972). X marks location of site investigation (plate 1). 
and a profile of the clay mineralogy (Appendix A) and physical properties of the Pierre Shale was determined in a trench (27 $\mathrm{m}$ long and 2.9-3.6 $\mathrm{m}$ deep) excavated perpendicular (N. $68^{\circ}$ E.) to the strike (N. $\left.22^{\circ} \mathrm{W}.\right)$ of the Pierre Shale, and in a core hole drilled on the trench to a depth of $27 \mathrm{~m}$ ( $p l a t e 1)$. Additional subsurface structural data were obtained from a 92-m-long, highresolution seismic reflection survey (Appendix B) parallel to the excavated trench ( $\mathrm{plate} 1$ ). The survey extended beyond the trench about $25 \mathrm{~m}$ to the west and $40 \mathrm{~m}$ to the east.

Because of apparent westerly thickening of the surficial deposits, the trench excavation began approximately $20 \mathrm{~m}$ east of the approximate location of the Golden fault trace, as mapped by Scott (1972), and $56 \mathrm{~m}$ north of Quincy Avenue. The core hole was located directly over the trench, $21 \mathrm{~m}$ northeast of the beginning of the trench excavation, and was drilled to a depth of $27 \mathrm{~m}$, $3 \mathrm{~m}$ below the deepest chemical weathering observed in the shale cores at $24 \mathrm{~m}$. Air was used as a drilling fluid to a depth of $10 \mathrm{~m}$, where a perched water table was intercepted; below this, a heavy mist was used to the final depth of $27 \mathrm{~m}$ in order to obtain minimally disturbed core samples.

Three geologic units mapped in the trench are shown on the cross section in plate 2 and described below. Additional descriptive information for unit 3 (Pierre Shale) taken from the drill-hole core logs is also included. The cores, except for the vertical direction, are unoriented; therefore, strike and dip directions of geologic structures observed in the cores are unknown.

Unit 1 is a modern, dark, humic-soil horizon, approximately $30 \mathrm{~cm}$ thick, developed on the present-day surface of Slocum alluvial deposits mapped by Scott (1972).

Unit 2 is poorly sorted, pink to reddish-brown alluvium containing numerous angular to well-rounded boulders (up to $1 \mathrm{~m}$ diameter), cobbles, and pebbles interspersed randomly in a fine-grained matrix consisting of micaceous, silty, fine- to medium-grained sand, having little or no stratification. The deposit, approximately $3 \mathrm{~m}$ thick and overlying the Cretaceous Pierre Shale, is mapped as the Slocum alluvium (Scott, 1972) of Pleistocene age. At this location, the alluvium was derived from the sedimentary and granitic rock sections of the adjacent uplifted Front Range of the Rocky Mountains and appears to have the composition and particle-size distribution similar to that of a complex debris flow (Varnes, 1978). Such a heterogeneous mass of angular to well-rounded rock fragments contained within a fine-grained transporting matrix indicates very rapid deposition.

Unit 3, the Upper Cretaceous Pierre Shale, is an upturned section of highly weathered marine shale with distinct bedding that strikes approximately N. $30^{\circ} \mathrm{W}$. and dips between $65^{\circ}$ and $90^{\circ}$ northeast. Clay and bulk mineralogy (determined by Eberl (Appendix A)), and grain-size distributions (fig. C-1, Appendix $C$ ) of the shale were determined from selected trench and core 
samples. With the exception of eleven distinct but irregularly spaced clayey to sandy seams parallel to bedding, the shale has a uniform lithology that consists of a yellow-brown to olive-gray smectitic clay (Appendix A) with finely interbedded silt and fine sands. As a result of weathering, the shale in the trench is oxidized and extensively fractured along bedding planes with occasional horizontal fractures; however, there is no visual evidence of a soil horizon developed in the shale below the sharp contact with the overlying al luvium.

The distinct seams mapped in the trench parallel to bedding (plate 2) are features contemporary to the shale deposition, but they have been modified by later erosional and weathering processes. All of these contain abundant fine-grained quartz and probably originally were interlayered between the clay deposits within the Pierre Shale. After the shale was uplifted and tilted by Cenozoic tectonic activity, a period of subaerial weathering and erosion took place allowing an oxidized weathered zone to develop in the tilted shale deposits. During Pleistocene, probably an interglacial time, it is hypothesized that a reducing bog environment developed above the weathered surface of the tilted shale allowing iron, manganese, and carbonate-rich, acidic-surface waters to percolate down through the fine-grained sand beds. Upon encountering the oxidized environment of the weathered shale, $\mathrm{MnO}, \mathrm{FeO}$, and $\mathrm{CaCO}_{3}$ were precipitated in these beds. In addition, the percolating waters deposited and concentrated clay minerals derived from overlying shale deposits. The Slocum alluvium was then deposited in such a forceful manner that it obliterated all vestiges of the existing surface environment on the shale. The mineralogy of the individual seams mapped in the trench, as analyzed by Eberl, is described in Appendix A.

From the drill hole, core logs show that the weathering profile of the oxidized and fractured shale extends gradationally to a depth of $24 \mathrm{~m}$ below the surface. The most severe weathering occurred to a depth of $10 \mathrm{~m}$, where the drill intercepted a perched water table. Core recovered in this interval (27 percent recovery) had nearly the same lithology and clay mineralogy (Appendix A) and appeared to be nearly as fractured as the shale described in the trench except that there were fewer bedding-plane fractures and more horizontal fractures with vertical spacings of approximately $3 \mathrm{~cm}$. These likely account for the poor core recovery. Below 10-m depth, the shale lithology and clay mineralogy (Appendix A) remained much the same, except for a slight decrease of the exchangeable $\mathrm{Ca}^{2+}$ cation near the base of the weathered layer, but the weathering gradually decreased with depth and core recovery increased from 58 percent at $13 \mathrm{~m}$ to 100 percent at $20 \mathrm{~m}$. Cores from the 10-24 $\mathrm{m}$ interval became less oxidized and were less fractured. Beddingplane fractures were less numerous, but widely spaced (greater than $8 \mathrm{~cm}$ ) horizontal fractures and high-angle conjugate shear fractures were dominant. Typically, many of the high-angle shear fractures and some of the horizontal 
fractures below $18 \mathrm{~m}$ were filled with gypsum 2-4 mm thick. There were two zones of badly fractured and deformed rock in the weathered profile at $10-11.5 \mathrm{~m}$ and at $18.3-20.0 \mathrm{~m}$.

The shallower zone, between $10 \mathrm{~m}$ and $11.5 \mathrm{~m}$, consists of brecciated shale interspersed between a series of nearly horizontal or low-angle fractures with an average spacing of approximately $4 \mathrm{~cm}$ (fig. 2). The breccia contains gouge and rotated rock fragments as large as $5 \mathrm{~cm}$ across. Although fault displacements could not be measured, some horizontal deformation was noted and bedding-plane dip orientations were rotated at least $35^{\circ}$ (from $80^{\circ}$ to $65^{\circ}$ in the opposite direction), indicating possible faulting in this zone.

The deeper zone between $18.3 \mathrm{~m}$ and $20.0 \mathrm{~m}$ contained horizontal fractures, steeply dipping conjugate shear fractures, and had a fault (dipping $65^{\circ}$ ) that cut across the bedding. Because of the uniform lithology, displacements are nearly impossible to determine. The fault contains as much as $1.5 \mathrm{~cm}$ of compacted gouge that consists of ductilely deformed shale and rock fragments lightly bonded with a calcareous cement. In some locations, displacements have deformed the gypsum deposits filling previously formed fractures. The bedding above the fault dips approximately $75^{\circ}$ in the opposite direction to that of the fault, and below the fault bedding is nearly vertical.

At 24-m depth, the boundary between the weathered and nonweathered shale consists of horizontal fractures with small drag folds, indicating some horizontal movement. Below $24 \mathrm{~m}$ to the end of the drill hole at $27 \mathrm{~m}$, the shale showed no signs of oxidation or chemical weathering. The only fractures observed were high-angle conjugate shears and horizontal extensional fractures. The shear fractures cut across bedding planes and were covered with slickensides. None of the fractures contained gypsum filling.

Additional structural information obtained from the seismic profile is interpreted from refraction-observed data. Under the drill-hole location, nearly horizontal refraction breaks are interpreted by Williams and King (Appendix B) to represent a soil layer to approximately $1-\mathrm{m}$ depth, alluvium to approximately 4-m depth, drier shale to approximately 8-m depth, and saturated shale below 8-m depth. There is a vertical offset of about $2 \mathrm{~m}$ on the drier shale surface beyond the southwest end of the excavated trench. The profile (fig. B-3, Appendix B) has approximately a 5.8:1 horizontal-to-vertical exaggeration. 


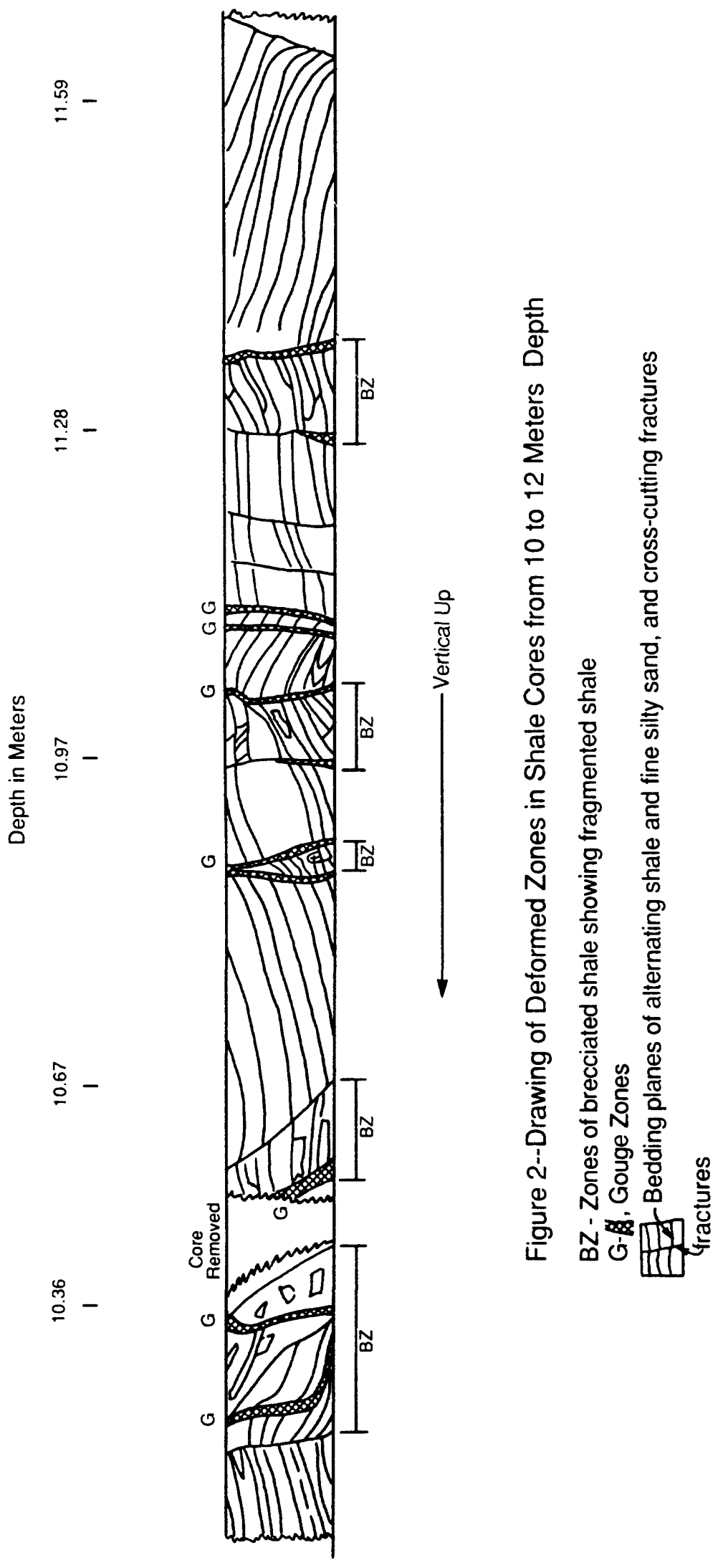




\section{DETERMINATION OF PHYSICAL PROPERTIES}

Samples from the trench and cores from the drill hole were used to determine bulk density, grain density, moisture content, porosity, degree of saturation, Atterberg limits, and grain-size distribution; the results are shown on table $C-1$, and figure $C-1$, Appendix $C$, and plate 3 . Measurements were made with portable field-laboratory apparatus set up at each location and in standard laboratory facilities. Field measurements were made of moisture contents and bulk densities immediately after the extraction of samples in order to obtain values as near as possible to the undisturbed in-situ conditions. Average values of bulk density, moisture content, and porosity are shown as a function of depth in plate 3.

\section{EVIDENCE FOR REBOUND}

At the location of the investigation, the only soil horizon was that observed above the non-clayey Slocum alluvial deposit. Since the top of the underlying Pierre Shale was visually devoid of a recognizable soil horizon, swelling soil properties could not be evaluated here. However, the data obtained do allow an evaluation of the natural rebound and potential rebound damage to structures caused by construction practices.

Rebound (Nichols, 1980) in this text is considered to be the expansive recovery of the Pierre Shale in response to natural or engineering excavations, which are usually excavations of overburden loads. Since the excavations are directly above the rebounding shale still horizontally confined, most of the expansion takes place in the vertical direction, and the resulting increase of volume is increased void space that absorbs available pore water. The unaltered shale below 24-m depth is assumed to have undergone very little rebound expansion; therefore, the clay fabric is still relatively intact. The physical properties of samples taken from this depth, when compared to shallower samples, show them to be the most dense and to have the lowest water content, even though they are completely saturated ( $p l a t e 3)$. The clay mineralogy of the unaltered shale has slight differences of exchangeable cations compared to those in the weathered shale sampled above. There is a perceptible decrease of smectite expandability (90 to 80 percent) in the weathered clays above 24-m depth (Appendix A), an indication of the increase of the divalent ion $\mathrm{Ca}^{2+}$ obtained from permeating ground water in fractures and sandy layers. The dominance of the divalent cation in the smectite/illite 001 layer tends to stabilize the hydration layer at about $15 \AA$ until saturation is attained and then stabilizes at $19 \AA$ (MacEwan and Wilson, 1980). The calcium-rich waters also precipitate out gypsum in fractured zones of the weathered rock. Although rebound deformations probably have occurred at greater depths, other physical-properties measurements from the Pierre Shale of Colorado (Collins and Nichols, 1987) and South Dakota (Nichols and others, 1986) indicate very little expansive volume change below the weathered 
zone except where there is extensive fracturing or faulting. Sample properties from the 26-m depth, therefore, are used to represent the relatively undisturbed conditions of the shale prior to destructive rebound deformations. All of the properties determined on the remaining core samples taken above this depth are used for a comparison of the volume changes that have occurred at shallower depths. Plate 3 shows a vertical profile of the depths, the increased changes of volume, and pore-water contents of all cores with respect to the undisturbed cores taken from the 26-m depth (sample calculations for these data are shown in Appendix C). The locations of the weathered zone, fractured and faulted zones, and a perched water table are shown on the profile, illustrating their effect on the core volume increase and water absorption.

Above the undisturbed shale at the 26-m depth, the volume shows increases of approximately 6.4 percent up to the $22-\mathrm{m}$ depth, where it is locally affected by a fault zone (plate 3 ) from 22-18 $\mathrm{m}$. Above this depth, the volume remains approximately constant (6-8 percent greater than undisturbed samples) up to a depth of $4 \mathrm{~m}$, except in the fractured zone at the base of the perched water table. Above $4 \mathrm{~m}$, there is nearly a 20 percent volume increase at less than $2 \mathrm{~m}$ below the shale-alluvium contact. Between $18 \mathrm{~m}$ and $22 \mathrm{~m}$, there is an 8-10 percent volume increase associated with a fault zone. Between $7 \mathrm{~m}$ and $12 \mathrm{~m}$, there is an 8-14 percent volume increase associated with a horizontally displaced fracture zone containing a perched water table.

The pore-water content increases with decreasing depth in a similar manner to the pore-volume increase, except that it is progressively less than the pore-volume increase; thus, the saturation of the cores becomes progressively less toward the surface. Saturation values are shown in parentheses next to each depth location in plate 3. Also, the pore-water content and pore volume have similar increases related to the fracture, fault zones, and perched water table. Based on the described patterns of pore and pore-water-volume increases, the volume of the slightly weathered shale above the undisturbed shale initially rebounds, maintaining saturation to a depth of $22.4 \mathrm{~m}$. Here, with the inferred addition of small amounts of ground water, available pore water is sufficient to completely fill the increased pore space. The 6.4 percent rebound at this depth probably initially results from the release of recoverable strain energy caused by weathering-induced relaxation of diagenetic clay and chemical bonds (Bjerrum, 1967; Russell and Parker, 1979) and possible additional swelling as available ground water is absorbed by clays. The illite/smectite clays at this depth have a slight increase of the $\mathrm{Ca}^{2+}$ cation, which imparts more stability to the 001 spacing at 14-15 $\AA$ (Appendix $A$ ). Typically, these clays remain stable until saturated and then become stable at $19 \AA$ spacing (MacEwan and Wilson, 1980). According to Bjerrum, however, recoverable strain energy, stored in flexible clay particles deformed by past consolidation pressures, is locked in the shale by diagenetic clay bonds. Upon disintegration of these bonds, the strain energy 
is relieved causing expansion of the shale fabric. Above 22-m depth, expansion exceeds the ability of available pore water to flow in, leaving the shale only partially saturated. Because the 14-15 \& clays are likely to remain stable as they become less saturated, they probably do not contribute to the expansion. Also, as the shale above $22 \mathrm{~m}$ becomes progressively less saturated, it is doubtful that osmotic pressure gradients contribute to the rebound volume expansion.

A very distinct increase of rebound and increased pore-water volumes in the vicinity of the fault, perched water-fracture zones, and the very shallow, highly weathered shale (plate 3 ) indicate that these features greatly enhance the rebound process. Between $18 \mathrm{~m}$ and $21 \mathrm{~m}$, the faulted shale along gypsum and gouge-filled fractures appears to have had displacements both prior to and after the gypsum emplacement. Disruption of the shale fabric during repeated faulting events has allowed relaxation of diagenetic clay and chemical bonds in addition to that produced by weathering (Russell and Parker, 1979), thereby permitting recoverable strain energy to cause subsequent volume increases (Bjerrum, 1967). The resulting increase of permeability allows ingress of new pore water that may possibly cause additional small volume increase by swelling of clays. However, the confining pressure at this depth does not permit a very large rebound volume (only about 8-10 percent greater than the undisturbed shale); even so, there is either an insufficient source of pore water or the permeability of the shale is so low that the vacant pores become only partly filled, thereby leaving the shale only partially saturated (96-98 percent). Between $7.5 \mathrm{~m}$ and $12.7 \mathrm{~m}$ (the highly fractured zone containing a perched water table), volume rebound exceeded 13 percent of the undisturbed shale, and again the available pore water was unable to fill the vacant pores (plate 3 ). The decreased confining pressure at this shallower depth allowed substantially larger rebound volume, but the saturation was only 92.5 percent even though a perched water table was present. Above the 7.5-m depth, the shale in the upper part of the weathered zone is highly fractured with minimum confinement, and the volume rebound near the upper shale boundary approaches a 20 percent increase over the undisturbed shale (plate 3 ). This is the largest expansion for the total profile, yet it has the lowest saturation (only 86 percent); again the available moisture is unable to fill the increased pore volume. The data indicate that available pore moisture generally fills no more than half of the expanded pore space; thus, the contribution to rebound due to swelling clays caused by water absorption cannot be defined without more definitive clay fabric studies.

The rebound represented by increasing pore volume on this profile becomes greater towards the surface. Rebound is inversely related to increasing confining pressure, but locally it appears to be directly related to the degree of breakup of diagenetic bonds in the clay matrix caused by weathering and fracturing; that is, maximum expansion occurs in the highly fractured and weathered zones nearest to the surface. In-situ experiments performed by mechanical pressurization of borehole walls in the Pierre Shale 
of South Dakota demonstrated the occurrence of time-dependent expansion of bedrock caused by fracturing and unloading the in-situ shale (Nichols and others, 1986).

The pore-water content also increases toward the surface and in the highly deformed zones but is decreasingly able to maintain saturation of the increased pore volume and, therefore, may not cause further swelling of the al ready stable hydration state of the 14-15 $\AA$ clays. Even in zones of fabric deterioration caused by fracturing and faulting where pore water may be abundant, saturation of the clay matrix is not maintained, which suggests that the absorption does not keep up with volume increase. Therefore, the volume increase logically precedes the inflow of pore water that may be accommodated by increased permeability. At the $6.6-\mathrm{m}$ depth above the perched water table, there has been a 6 percent volume increase but no increase of pore water to fill the vacant voids, which indicates that at this location, the shale above the perched water table has limited access to percolating ground water or fracture aquifers supplied by surface runoff. This implies that the fracture zone and perched water table existing below are associated with a vertical fracture system at some location other than at our drill-hole profile. In addition, the volume expansion appears to be independent of changes in the clay mineralogy, which remains relatively constant for the suite of samples tested from the vertical profile.

The data on the profile demonstrate the probability that any removal of overburden down to $4 \mathrm{~m}$ is likely to be followed by expanding bedrock with a volume increase as much as 14 percent greater than that of the unweathered clay, mostly in a time-dependent or ductile manner. This kind of timedependent behavior has been demonstrated on newly extracted cores removed from shallow depths in the Pierre Shale of South Dakota (Nichols and others, 1986), also by time-dependent rebound after excavation of the shale for highway construction (Collins and others, 1989) and by rebound on the stilling-basin floor during construction of the Oahe Dam in South Dakota (Underwood and others, 1964).

\section{SEISMIC-DATA INTERPRETATION}

The seismic-refraction data (Appendix B) verify the boundaries of the soil horizon, Slocum alluvium, and the top of the Pierre Shale, but not the steep dip of the bedding in the shale. Near the shale-alluvium contact between 2-m and 4-m depth, a significant density increase of the shale (plate 3 ) causes a seismic-velocity increase sufficient to produce a refraction horizon. At approximately 7.5-m depth, another refraction horizon occurs at the fracture zone containing a perched water table (plate 3) lying above a wetter, but not totally saturated shale. Below this depth, the configuration of the seismic profile does not allow for deeper energy recovery. 
Based on the seismic-refraction data (Appendix B), the horizon near the surface of the Pierre Shale at $4.2 \mathrm{~m}$ contains a distinct offset (approximately $2 \mathrm{~m}$ ) between stations 155 and 160 . The offset, however, does not appear to exist on the deeper refraction horizon at $7.5 \mathrm{~m}$ just above the horizontal fracture zone and perched water table, but there is an anomalous refraction point here. Movement on the Golden fault, approximately located beyond the southwest end of our trench ( $p$ late 1), may have caused displacement of the shale-alluvium contact. If this is the case, then the horizontal fracture zone and perched water table appear to postdate or coincide with singular or recurrent fault movements. The anomalous refraction on the lower horizon may represent possible movement on a local structure created by recurrent fault movement. This horizon is nearly horizontal for the length of the refraction profile, and the drill-hole cores demonstrate evidence of horizontal deformation (fig. 2), which indicates the possibility that faulting or erosional rebound associated with faulting may have been responsible for the fracture zone (Nichols and others, 1986). Unfortunately, logistics did not allow for further trenching needed to expose the fault for verification of these relations.

\section{CONCLUSIONS}

The data gathered from this investigation deal mostly with the understanding of natural rebound in the Pierre Shale that has resulted from erosional removal of overburden. The profile of physical properties, and mineralogical and geological descriptions that help to define structural influences and the progression of natural rebound in a vertical section, permit a prediction of problems that may occur with the removal of overburden by engineering excavations and disturbances. Upon removal of any of the upper portion of weathered shale or covering alluvial deposits, time-dependent rebound probably will occur within the shale. The amount of rebound at the surface generally depends on the amount of overburden excavated; the amount of rebound that already has occurred in the shale below the excavation; the degree of saturation; the existence of faults, fracture zones, or any other structures introducing major bedrock inhomogeneities; the condition of rebound equilibrium prior to excavation; and the depth and content of alluvium still remaining above the shale. In addition, the amount of rebound will depend on the constraint of the structures built on the excavation site and the type and amount of fill added above the excavation surface.

For example, if an excavation were made at the location of our drill hole by removing the alluvium and $2 \mathrm{~m}$ of shale, the expected possible timedependent rebound would be as much as 13 percent of the unweathered shale and may extend to a depth of at least $2 \mathrm{~m}$ below the new surface. The effects of engineering construction on the rates and displacements produced by rebound at the excavation surface are impossible to predict without post-excavation displacement measurements. Additional geotechnical measurements are needed to 
evaluate the effects of degree of saturation, existence of bedrock fracturing and faulting, remaining bedrock rebound potential, and restraints caused by structural loading.

\section{RECOMMENDATIONS}

Rebound deformations in the Pierre Shale, in addition to deformations caused by derived swelling soils, may be sufficient to cause serious ongoing damage to recently constructed buildings, highways, and buried utilities in the area of concern. It is difficult to recommend construction practice without first obtaining information on the physical condition of the shale bedrock in areas where construction has disturbed the natural physical profile and where geologic structures may possibly have been activated by natural forces. Faulted areas may experience linear differential-rebound displacements critical to the integrity of overlying foundations. Some construction practices that have already proven successful under new foundations are (1) covering over the shale bedrock with non-shale-derived fill that will absorb differential displacements under the foundations (Kline, 1982), and (2) knitting together the shale bedrock with anchor bars, which are then grouted to the foundations (Underwood and others, 1964). Perhaps smaller structures may even be designed with a foundation on which much of the load may be transmitted to a centrally located pad and supporting caisson. Probably the most cost-effective solution is to develop engineering procedures based on a model of the rebound process. Such a model may be developed through continuing field and laboratory studies on geologic and physicalproperties profiles and related rebound displacements induced by construction practice. Appropriate detailed site investigations, prior to and after the excavation of shallow overburden deposits above the Pierre Shale, can be made in conjunction with maintenance projects within already damaged areas. 


\section{REFERENCES}

Bjerrum, L., 1967, Progressive failure in slopes of overconsolidated plastic clay and clay shales: American Society of Civil Engineers, SM 2, p. 3-49.

Collins, D.S., and Nichols, T.C., Jr., 1987, Preliminary data report conducted for the Colorado State Geological Survey on the Superconducting Supercollider Study: U.S. Geological Survey Open-File Report 87-55, p. 1-13.

Collins, D.S., Swolfs, H.S., and Nichols, T.C., Jr., 1988, Highway damage related to faults near Pierre, South Dakota: U.S. Geological Survey Open-File Report 88-674, 42 p.

Kirkham, R.M., and Rogers, W.P., 1981, Earthquake potential in Colorado: Colorado Geological Survey Bulletin 43, p. 1-171.

Kline, J.H., 1982, Natural and man-made factors that influence property damage due to swelling soils in southeastern Jefferson County, Colorado: Golden, Colorado School of Mines M.S. thesis, $182 \mathrm{p}$.

MacEwan, D.M.C., and Wilson, M.J., 1980, Interlayer and intercalation complexes of clay minerals, Chapter 3 in Brindley, G.W., and Brown, G., eds., Crystal Structures of Clay Minerals and Their X-Ray Identification: London, Mineralogical Society Monograph No. 5, p. 197-248.

Nichols, T.C., Jr., 1980, Rebound, its nature and effect on engineering works: Quarterly Journal of Engineering Geology, v. 13, p. 133-152.

Nichols, T.C., Jr., Collins, D.S., and Davidson, R.R., 1986, In-situ laboratory geotechnical tests of the Pierre Shale near Hayes, South Dakota--A characterization of engineering behavior: Canadian Geotechnical Journal, v. 23, p. 181-194.

Russell, D.J., and Parker, A., 1979, Geotechnical, mineralogical, and chemical interrelationships in weathering profiles of an overconsolidated clay: Quarterly Journal of Engineering Geology, v. 12, p. 107-116.

Scott, G.R., 1972, Geologic map of the Morrison Quadrangle, Jefferson County, Colorado: U.S. Geological Survey Miscellaneous Investigations Map I-790-A, scale $1: 24,000$.

Strazer, R.J., Bestwick, L.K., and Wilson, S.D., 1974, Design considerations for deep retained excavations in overconsolidated Seattle clays: Association of Engineering Geologists Bulletin, v. 11, no. 4, p. 379-398.

Underwood, L.B., Thorfinnson, S.T., and Black, W.T., 1964, Rebound in design of Oahe Dam hydraulic structures: American Society of Civil Engineers Journal of the Soil Mechanics and Foundations Division, 90(SMI), p. $1-27$.

Varnes, D.J., 1978, Slope movement types and processes, in Schuster, R.L., and Krizek, R.J., eds., Landslides, analys is and control: Transportation Research Board, National Academy of Sciences, Special Report 176, p. 11-33. 


\section{APPENDIX A}

Report from D.D. Eberl, U.S. Geological Survey, on the clay mineralogy of selected samples from the Pierre Shale. Samples were collected from the trench and core hole at the site of investigation (fig. 1). 
The samples submitted for X-ray analyses were taken from trench and core samples.

Samples $1,3 \mathrm{~A}, 3 \mathrm{~B}, 4,5,6 \mathrm{~A}, 7$, and 8 from the trench were taken from seams $1,3,4,5,6,7,8$, and 10 respectively ( $p l$ ate 2 ).

Samples 66 and $A 4$ were selected in the trench at the drill-site location at $2.51 \mathrm{~m}$ and $2.96 \mathrm{~m}$ from the surface.

Samples $\mathrm{C} 1$ through C10-6 were core samples taken at depths from the surface as follows:

Sample No.

C1

C2

C3-1

C5-1

C6-2

C7-2

C8-4

C9-2

C9-5

C10-3

C10-6
Depth (m)

4.00

6.63

7.93

10.21

13.11

16.07

18.60

22.56

23.48

25.30

25.91 


\begin{tabular}{|c|c|c|c|c|}
\hline Sample & Clay fraction & $001 \operatorname{air}(\AA)$ & $\% \exp$ & Coarse minerals \\
\hline 1 & $\mathrm{I} / \mathrm{S}, \mathrm{I}, \mathrm{K}, \mathrm{C}(?), \mathrm{Q}(?)$ & 13.13 & 80 & $Q, F, C, G o(?)$ \\
\hline $3 \mathrm{~A}$ & $\mathrm{I} / \mathrm{S}, \mathrm{I}, \mathrm{K}, \mathrm{C}, \mathrm{Ch}(?), \mathrm{F}, \mathrm{Q}$ & 14.25 & 80 & $C, Q$ \\
\hline $3 B$ & $\mathrm{I} / \mathrm{S}, \mathrm{I}, \mathrm{K}, \mathrm{C}, \mathrm{Ch}(?), \mathrm{F}, \mathrm{Q}$ & 14.16 & 80 & $Q, F$ \\
\hline 4 & $\mathrm{I} / \mathrm{S}, \mathrm{I}, \mathrm{K}, \mathrm{C}, \mathrm{F}, \mathrm{Q}$ & 13.56 & 80 & $C, Q$ \\
\hline 5 & $\mathrm{I} / \mathrm{S}, \mathrm{I}, \mathrm{K}, \mathrm{C}, \mathrm{Ch}(?), \mathrm{F}, \mathrm{Q}$ & 14.26 & 80 & $C, Q$ \\
\hline $6 \mathrm{~A}$ & $\mathrm{I} / \mathrm{S}, \mathrm{I}, \mathrm{K}, \mathrm{C}, \mathrm{F}, \mathrm{Q}$ & 14.31 & 80 & $c, Q$ \\
\hline 7 & $I / S, I, K, C, C h(?), F, Q$ & 14.32 & 80 & $C, Q, F$ \\
\hline 8 & $\mathrm{I} / \mathrm{S}, \mathrm{I}, \mathrm{K}, \mathrm{Ch}, \mathrm{F}, \mathrm{Q}$ & 14.24 & 90 & $Q, F$ \\
\hline 66 & $\mathrm{I} / \mathrm{S}, \mathrm{I}, \mathrm{K}, \mathrm{Ch}, \mathrm{F}, \mathrm{Q}$ & 14.25 & 80 & $Q, F$ \\
\hline A4 & $\mathrm{I} / \mathrm{S}, \mathrm{I}, \mathrm{K}, \mathrm{C}, \mathrm{Ch}(?), \mathrm{F}, \mathrm{Q}$ & 14.17 & 90 & $Q, F$ \\
\hline GY & N.A. & N.A. & N.A. & $G, Q, C h(?), R(?)$ \\
\hline C1 & $\mathrm{I} / \mathrm{S}, \mathrm{I}, \mathrm{K}, \mathrm{Ch}(?), \mathrm{F}, \mathrm{Q}$ & 14.36 & 80 & $Q, F, D(?)$ \\
\hline C2 & $\mathrm{I} / \mathrm{S}, \mathrm{I}, \mathrm{K}, \mathrm{F}, \mathrm{Q}$ & 14.19 & 80 & $Q, F, D(?)$ \\
\hline C3-1 & $\mathrm{I} / \mathrm{S}, \mathrm{I}, \mathrm{K}, \mathrm{Ch}(?), \mathrm{F}, \mathrm{Q}$ & 14.15 & 80 & N.A. \\
\hline C5-1 & $\mathrm{I} / \mathrm{S}, \mathrm{I}, \mathrm{K}, \mathrm{F}, \mathrm{Q}$ & 14.12 & 80 & $Q, F, D(?)$ \\
\hline c6-2 & $I / S, I, K, F, Q$ & 13.88 & 80 & $Q, F, D(?)$ \\
\hline C7-2 & $I / S, I, K, F, Q$ & 13.76 & 90 & $Q, F, D(?)$ \\
\hline C8-4 & $I / S, I, K, F, Q$ & 14.29 & 90 & $Q, F, D(?)$ \\
\hline C9-2 & $I / S, I, K, F, Q$ & 13.60 & 90 & $Q, F, D(?)$ \\
\hline c9-5 & $I / S, I, K, F, Q$ & 14.23 & 80 & $Q, F, D(?)$ \\
\hline C10-3 & $\mathrm{I} / \mathrm{S}, \mathrm{I}, \mathrm{K}, \mathrm{Ch}, \mathrm{F}, \mathrm{Q}$ & 14.02 & 90 & $Q, F, D(?)$ \\
\hline C10-6 & $\mathrm{I} / \mathrm{S}, \mathrm{I}, \mathrm{K}, \mathrm{Ch}, \mathrm{F}, \mathrm{Q}$ & 12.90 & 90 & $Q, F, D(?)$ \\
\hline
\end{tabular}

Symbols used in above table: $C=$ calcite; $C h=$ chlorite; $D=$ dolomite; $F=$ feldspar; $\mathrm{G}=$ gypsum; Go=goethite; I=illite; I/S=mixed layer $\mathrm{illite/smectite;} \mathrm{K=kaolinite;}$ $N . A .=$ not analyzed; $Q=$ quartz; R=rectorite.

The mineralogy of the clay-size fraction $(<2 \mu \mathrm{m})$ is very constant between samples, with the exception of the presence of calcite. The clay-size fraction is composed primarily of the following clay minerals: mixed-layer illite/smectite, discrete illite, and kaolinite. The $i 11$ ite/smectite has an expandability that lies between 80-90 percent. There may or may not be a very small amount of chlorite present in some samples. 0ther minerals in the clay-size fraction include calcite in some samples, quartz, and a small amount of feldspar. The position of the illite/smectite 001 of the air-dried sample is sensitive to interlayer chemistry: a 001 close to $12.5 \AA$ would indicate $\mathrm{Na}^{+}$as the dominant exchange ion, whereas a spacing close to $15 \AA$ would indicate a divalent ion such as $\mathrm{Ca}^{2+}$. Most of the 001 positions indicate that the exchange cations predominantly are divalent. This interlayer chemistry would tend to limit the swelling potential of these clays. 
The mineralogy of the coarse minerals (C-samples) is predominantly quartz and feldspar, with possibly some dolomite (identification based on one peak, the strongest at $2.88 \AA)$. The other samples vary between containing quartz and feldspar, and calcite and quartz. One sample (GY) is rich in gypsum.

The metallic minerals observed in seams parallel to shale bedding, typified by sample \#8, were determined by an SEM semi-quantitative analysis. The following analysis shows a fair amount of $\mathrm{Mn}$ and $\mathrm{Fe}$ in the sample.

Standardless Analysis

$20.0 \mathrm{KV} \quad 56.5$ Degrees

Chi-sqd $=2.40$

Element
Al-K
$\mathrm{Si}-\mathrm{K}$
$K-K$
$\mathrm{Ca}-\mathrm{K}$
$\mathrm{Fe}-\mathrm{K}$
$M n-K$
$\mathrm{Cu}-\mathrm{K}$
$\mathrm{Au}-\mathrm{M}$
$\mathrm{Mg}-\mathrm{K}$
$\mathrm{Ti}-\mathrm{K}$
$0.06150+1-0.00338$
$0.25666+/-0.00353$
$0.02400+/-0.00165$
$0.02217+/-0.00195$
$0.10441+1-0.00417$
$0.08303+1-0.00340$
$0.02390+1-0.00525$
$0.41129+1-0.00864$
$0.00690+/-0.00198$
$0.00614+/-0.00177$

Rel. K-ratio
Net Counts

$$
\begin{array}{r}
8140+/-448 \\
38284+/-527 \\
3107+/-214 \\
2665+/-234 \\
6006+/-240 \\
5593+/-229 \\
792+/-174 \\
28700+/-603 \\
726+/-208 \\
613+/-177
\end{array}
$$

ZAF Correction 20.00 KV $56.51 \mathrm{deg}$

No. of Iterations $=2$

\begin{tabular}{lccccrclr} 
Element & K-ratio & Z & A & F & Atom\% & Wt\% & Formula & Compound \\
\hline Al-K & 0.047 & 1.031 & 1.463 & 0.989 & 5.91 & 7.05 & Al203 & 13.32 \\
Si-K & 0.197 & 1.002 & 1.371 & 0.999 & 21.80 & 27.08 & Si02 & 57.94 \\
K-K & 0.018 & 1.049 & 1.094 & 0.991 & 1.21 & 2.10 & K 20 & 2.53 \\
Ca-K & 0.017 & 1.026 & 1.070 & 0.990 & 1.04 & 1.85 & Ca0 & 2.59 \\
Fe-K & 0.080 & 1.127 & 1.002 & 1.000 & 3.67 & 9.06 & Fe0 & 11.66 \\
Mn-K & 0.064 & 1.147 & 1.006 & 1.000 & 3.03 & 7.37 & Mn0 & 9.52 \\
Mg-K & 0.005 & 1.001 & 1.783 & 0.993 & 0.87 & 0.94 & Mg0 & 1.56 \\
Ti-K & 0.005 & 1.123 & 1.003 & 0.973 & 0.25 & 0.53 & Ti02 & 0.89 \\
O -K & 0.207 & 0.961 & 2.215 & 0.999 & 62.20 & $44.01 \mathrm{~S}$ & -- & -
\end{tabular}

$$
\text { Total }=100.00 \% \quad \text { Tota } 1=100.00 \%
$$


U.S.G.S. SEM LFE

Cursor: 0 Do0keV $=0$
THIJ QS-FIJG-90 $11: 17$

ROI CO) O Q00:10 $240=1758.43$

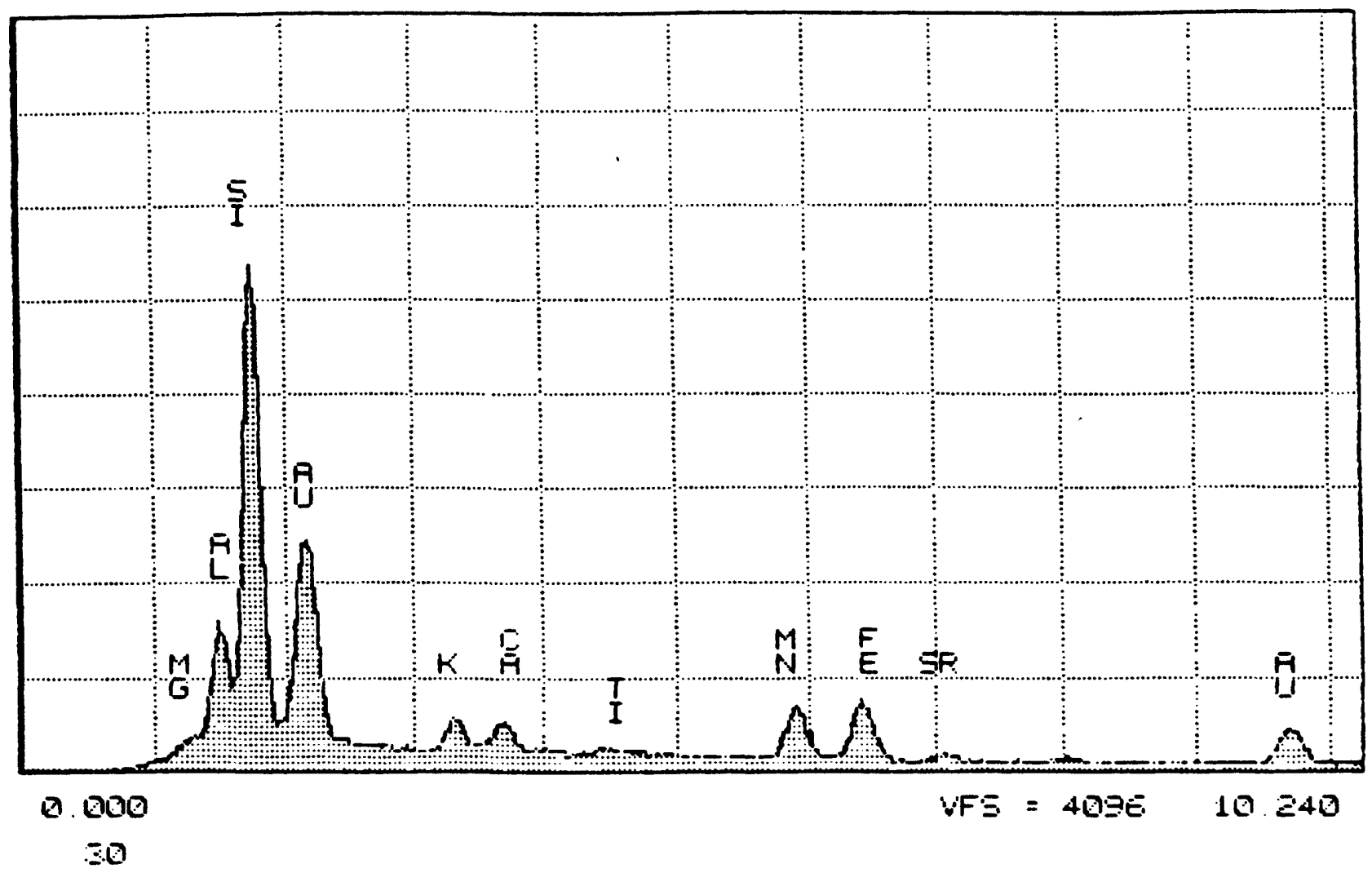

$\therefore 10: 100$ 


\section{APPENDIX B}

Report by R.A. Williams and K.W. King, A seismic investigation of shallow surface layers near Friendly Hills subdivision, Denver, Colo., interpreting the seismic refraction data obtained at the site of investigation ( $f$ ig. 1). 


\title{
A SEISMIC INVESTIGATION OF SHALLOW SURFACE LAYERS MEAR FRIENDLY HILLS SUBDIVISION, DENVER, COLORADO
}

\author{
by Robert A. Williams and Kenneth W. King
}

November 27, 1990

\section{INTRODUCTION}

In part I of this report the geologic details of the trench and borehole were discussed. This portion of the study used high-resolution seismic refraction methods to determine the subsurface compressional-wave seismic velocity structure of the trench and borehole area and also the areas along a line $50 \mathrm{~m}$ to the northeast and southwest of the trench. The geologic structure of the site was then inferred from the seismic velocity structure. Common-offset sections were also generated to provide data on the lateral changes in seismic velocity along the profile. Specific targets of the seismic work were to assess the presence of faults and fracture zones in the Pierre Shale, and document changes in lithology.

The original field work was acquired using seismic reflection field methods in hopes of detecting the above targets from about 3 to $30 \mathrm{~m}$ depth. But seismic reflections were not observed in the data, only direct arrivals, refractions, and surface waves, so instead, the refraction data and a common-offset section were used to produce a depth section covering 0 to $10 \mathrm{~m}$. One limitation of the refraction interpretation is that the seismic data were acquired with the seismic source always located at the southwest end of the linear recording string (end-on spread), so there are no data with a reversed source-geophone configuration that would help indicate the presence of dipping layers. This limitation did not appear to impair the analysis significantly as the trench and borehole data were available to verify and calibrate some of the refraction interpretation.

\section{DATA ACQUISITION AND ANALYSIS}

\section{Refraction Data}

One 134-m-long seismic profile was acquired on a relatively flat, gently sloping surface located along a line parallel to and about $10 \mathrm{~m}$ southeast of the northeastward trending trench and borehole. As described earlier from the trenching data the general lithology of the site places Slocum alluvium, containing an abundance of cobbles and gravel, at the surface, which is underlain by Pierre shale dipping $70^{\circ}$ east. The steep dip of the shale precludes seismic detection of bedding plane structures within the shale, but other structural features could perhaps be observed at the alluvium-shale 
contact, or within the shale itself if a structure has sufficient lateral extent.

Prior to the main part of data collection ten 24-channel seismic records were acquired to study the ambient seismic noise, induced signal level, and to determine the optimum field parameters such as, geophone spacing and source-geophone offset.

In these tests the recorded signal was varied from allowing all frequencies above $100 \mathrm{~Hz}$ to pass unfiltered, to a record with frequencies below $240 \mathrm{~Hz}$ strongly attenuated. Based on these preliminary field tests the main part of the data were acquired with single $100 \mathrm{~Hz}$ natural frequency geophones spaced at $0.61 \mathrm{~m}$ intervals, a 12-gauge shotgun seismic source spaced at $0.61 \mathrm{~m}$ intervals and offset $9.1 \mathrm{~m}$ from the nearest geophone, and a 24-channel digital recorder. The seismic signal produced by the vertical impact of the shotgun slug was digitally sampled at $0.25 \mathrm{~ms}$ intervals, lo-cut filtered at $180 \mathrm{~Hz}(-24 \mathrm{~dB} /$ octave) and written to magnetic tape for permanent storage. The dominant recorded frequency band is between 150 and $200 \mathrm{~Hz}$ which permits vertical resolution of about $1.0 \mathrm{~m}$ near the surface and $2.5 \mathrm{~m}$ at about $8 \mathrm{~m}$ depth.

Once it was determined the data contained no observable reflections individual 24-channel field records spaced at $6.0 \mathrm{~m}$ intervals were selected from the entire profile for refraction analysis (fig. B-1). A number at the top of each field record in figure 1 indicates the horizontal position at which the computed depths and seismic velocities were applied and plotted in figure 3. The source position in each of the records of figure 1 is about $8 \mathrm{~m}$ to the left (southwest) of the left-most trace (channel 1) of each record. As seen in figure 1 the record quality and character changes along the line, an indication that the seismic velocity, and perhaps the lithology, is not be laterally consistent. The lateral variations are observed seismically by changes in: (1) the first arrival times for near offset traces which increase from about 20 to $25 \mathrm{~ms}$ in the southwest part of the line to over $30 \mathrm{~ms}$ at the northeast end of the line (a $45 \%$ decrease in near-surface seismic velocity), and (2) first arrival patterns which form linear trends in distance and time in records 104, 114, and 124, then change to curving patterns in records 144 , 174, and 184. The curving first arrival patterns are indicative of non-uniform seismic velocity (steadily increasing or decreasing) layers. Non-uniformity of seismic velocity within specific layers means that the results in these areas will be approximate because the analys is is based on planar layers of uniform seismic velocity. Other complications in the interpretation arise from occasional interference from the shotgun airblast and apparent scattering events which interrupt the continuity of events on the middle traces of record 144 at about $45 \mathrm{~ms}$. The air-blast energy can be seen on records 124, and 234-274 as a linear trending signal that, starting from 


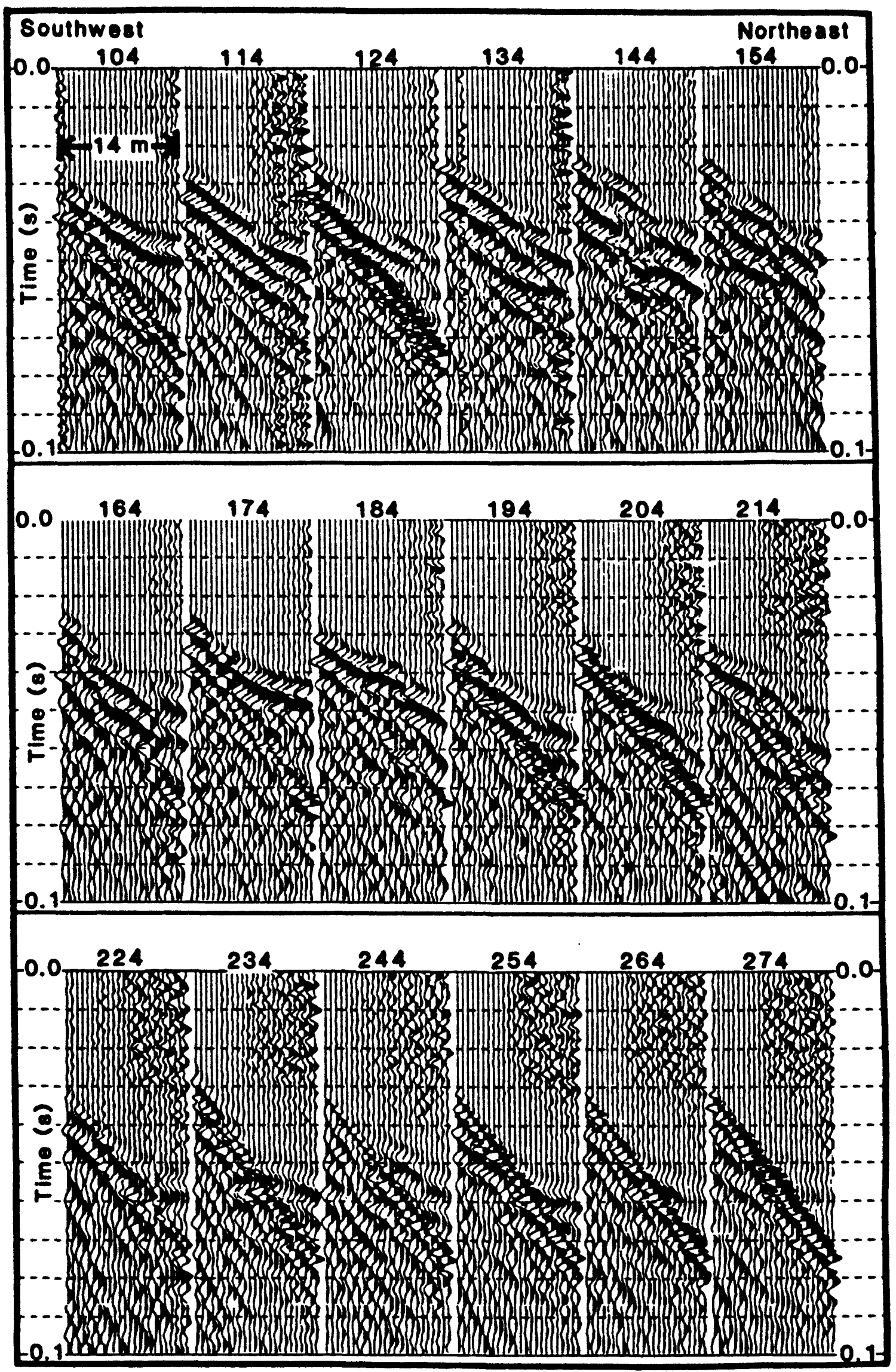

Figure B-1.--Raw field records showing the data that were used to produce the refraction interpretation. The numbers at the top of each record show the location at which the interpretation was applied in figure $B-3$. 
about $30 \mathrm{~ms}$ on the left, slopes down to the right to about $70 \mathrm{~ms}$. A high-speed first arrival can be seen on the far 6 or 8 traces of all records at about $40-42 \mathrm{~ms}$.

The slope-intercept method of analys is was applied to each of these records and provided about $10 \mathrm{~m}$ of horizontal subsurface data from each record. The subsurface position for the computed layer depths below the source-geophone spread was determined according to the method proposed by Mooney (1984). This method suggests that the computed layer depths are actually an average depth over a distance somewhat less than the length of the source-geophone spread. For this study the calculated layer depths and seismic velocities determined from a field record were applied to a subsurface position about $7 \mathrm{~m}$ from the source for that field record.

\section{Common Offset Data}

In the common offset procedure, the distance between the seismic source and receiver remains constant. Two common offset sections are presented in figure B-2: one was produced by extracting the $9.1 \mathrm{~m}$ offset trace (the nearest trace to the source - channel 1), and the other by selecting the $21.3 \mathrm{~m}$ offset trace (channel 21) of the 183 field records. The data on channel 1 appear to be direct arrivals, which allows examination of seismic data that has travelled only through the soil and alluvium, that is, the distance of channel 1 from the seismic source is not great enough to permit signals from the higher-speed clay to arrive first. Similarly, channel 21 was selected so that first arrivals would be refractions from the higher-speed signals travelling through the clay.

In figure B-2, the pairs of numbers annotated along the top of each section identify two station numbers: the top number is the shot location and the bottom number is the trace location. These station numbers are used again in figure 3 in describing seismic and lithologic features interpreted in the profile. The traces shown in figure $B-2$ have been scaled to equalize the amplitudes.

\section{RESULTS}

\section{Common Offset Data}

As seen in the top section of figure B-2, the first arrival times for the near trace vary between about 20 and $33 \mathrm{~ms}$ with longer travel times generally on the northeast end of the profile (first arrivals beyond station 231 are from the shotgun airblast). Since the ground surface along the profile is level the variability in first arrival times indicates that the seismic velocity in the upper $2 \mathrm{~m}$ is also varying, but is generally faster in the 


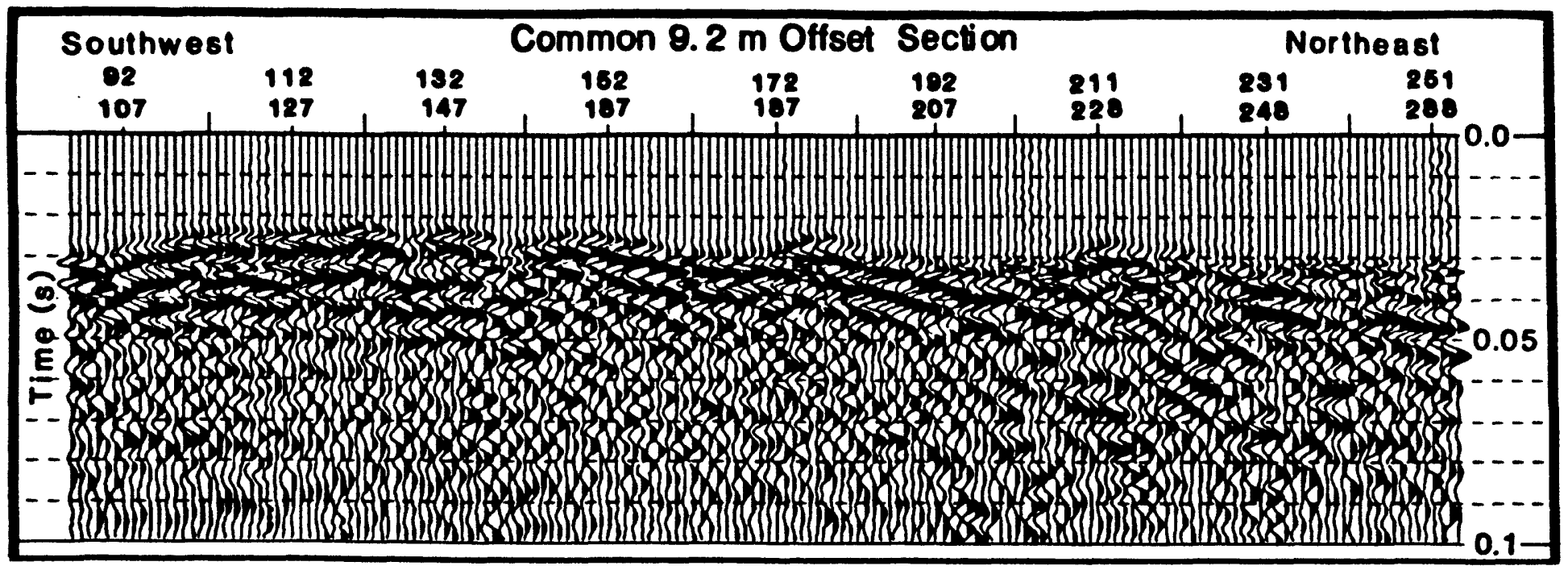

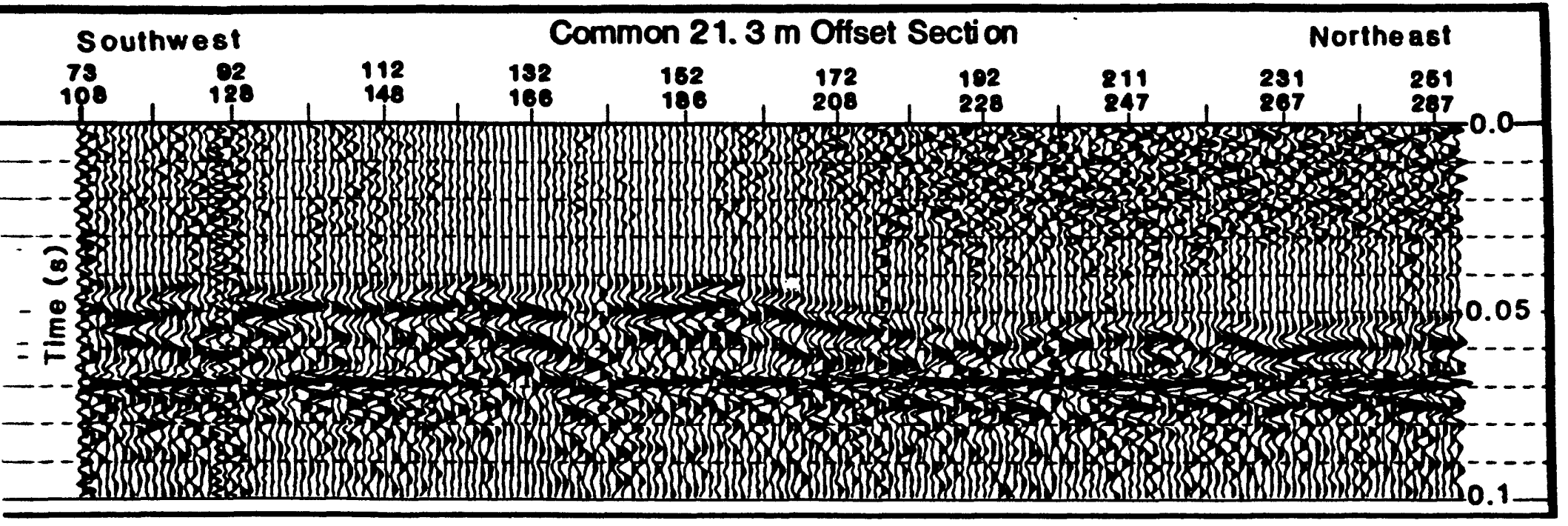

Figure B-2.--Two common offset sections produced by extracting the near trace from each field record (top) and trace 21 (bottom). The distance between each trace is $0.61 \mathrm{~m}$. 
southwestern half of the profile. The variability in seismic velocity could be caused by variations in moisture content or slight changes in lithology.

In the bottom section of figure B-2, the far trace arrival times are somewhat less variable than the near trace with the most notable trend being the longer travel times observed on traces in the northeast part of the line. The extra travel time for traces in the northeastern part of the line is roughly equivalent to the delay observed for the near trace, therefore, the arrival time delay for the far traces in the northeastern part of the line is due to slower velocities above this event rather than a change in depth. The strong event observed on the bottom section at about $69 \mathrm{~ms}$ is caused by the shotgun air blast.

\section{Refraction Data}

Analysis of the seismic refraction data generally indicates a four-layer structure from 0 to $30 \mathrm{~m}$ depth (fig. B-3), though only the upper three of the layers are lithologically unique; the fourth layer appears to be a saturated version of the third layer. These layers have distinctive seismic velocities of from 250 to $300 \mathrm{~m} / \mathrm{s}$ at the surface to about $1700 \mathrm{~m} / \mathrm{s}$ at about $8 \mathrm{~m}$ depth. The 250 to $300 \mathrm{~m} / \mathrm{s}$ layer represents a dry loose aerated soil zone that was seen as a brown layer at the top of the trench. The thickness of this soil layer was fairly uniform as observed in the trench, and within the seismic data resolution limits, it also appears as a uniformly thick layer.

Immediately below the surface layer the seismic velocity increases to a range of between 412 to $637 \mathrm{~m} / \mathrm{s}$ (fig. B-3). This layer, which probably represents the driest part of the slocum alluvium, appears to be less than one meter thick at the southwest end of the profile and up to 3 meters thick from the middle to the northeast end of the profile. This thickness change occurs abruptly at about station 160 and appears as a layer discontinuity in the depth section. However, the discontinuity is not observed either at the contact between layer 1 and 2 or between 3 and 4 . The computed depth of this layer northeast of station 160 is supported by the trench data.

Southwest of station 160 there is no trench, so the refraction interpretation becomes less reliable in this area, especially when considering that the recorded data in the region of the discontinuity are more complicated to interpret than elsewhere along the profile. These complications, which are probably caused by rapid near-surface lateral velocity changes as observed in the top section of the common offset profiles between geophone station 127 to 167 (fig. B-2), contribute to errors in the interpretation in the region of the velocity discontinuity because the refraction interpretation model depends on flat, laterally homogeneous seismic velocity layers. 


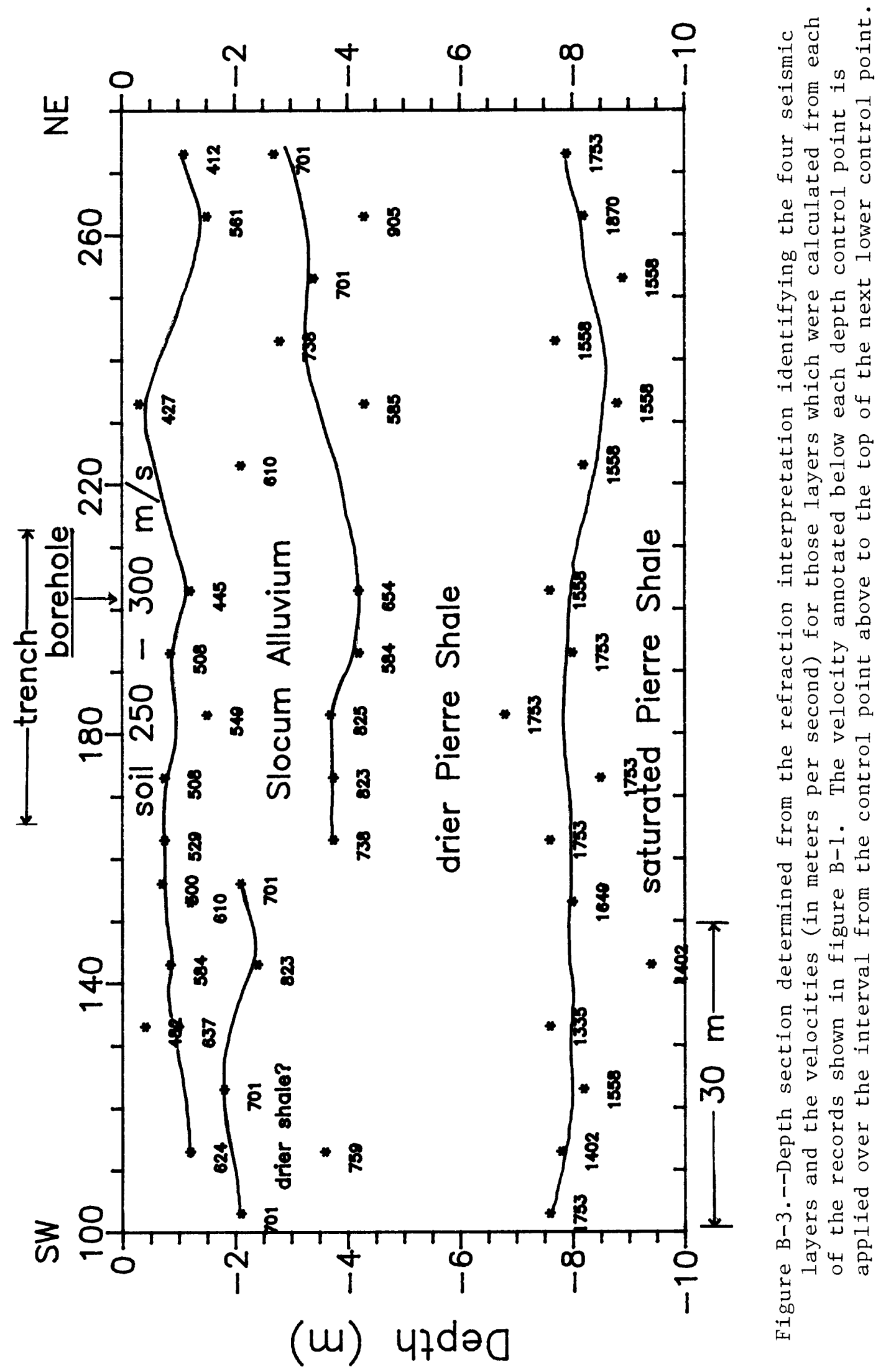


The detection of Pierre shale, layer 3 , is observed in the refraction data as an increase in velocity to about 650 to $825 \mathrm{~m} / \mathrm{s}$ (fig. B-3). This velocity is characteristic of an unsaturated, perhaps weathered, unconsolidated clay. At $4 \mathrm{~m}$ depth in the vicinity of the trench, refraction layer 3 is in good agreement with the depth to the shale top observed in the trench. This layer also becomes shallower to the northeast as observed in the trench. To the southwest of the trench projection zone the top of the shale is interpreted to be at only $2 \mathrm{~m}$ depth. This result conflicts with evidence from the trench which indicated that the shale-alluvium contact was trending deeper at the southwest end. Again, the complicated refraction arrivals in this region made it difficult to produce as precise an interpretation.

The top of layer 4 at about $8 \mathrm{~m}$ depth is marked by a doubling of seismic velocity to about 1550 to $1870 \mathrm{~m} / \mathrm{s}$ ( $\mathrm{fig} . \mathrm{B}-3$ ). This velocity is typical of saturated unconsolidated materials and corresponds to a saturated layer detected in the borehole. Within the resolution limits this layer appears to occur at a constant depth over the length of the profile with some anomalies at stations 144, 184, and 244. The relatively uniform depth of layer 4 is supported by the common offset data described above which showed that the travel time delays on the northeast part of the profile were caused by velocity changes in the material overlying layer 4 . If the seismic records with the greatest source-receiver distances are used then the minimum thickness for layer 4 is about $2 \mathrm{~m}$.

\section{Shear Wave Velocity Estimates From Surface Wave Data}

The following analysis of surface waves recorded in this investigation is provided for use in any future investigations. Since the surface wave velocity is a few percent slower than the shear wave (Aki and Richards, 1980), and because the shear wave was not recorded in this investigation, we measured the surface wave velocity to get an estimate of the shear wave velocity. The surface wave measurements were taken from field records similar to those shown in figure B-2. The surface wave velocity was measured at 4 locations along the profile to produce an average velocity of $214 \mathrm{~m} / \mathrm{s}$. Velocities at the southwestern end of the profile appear to be slightly faster than those from the northeastern end: $223 \mathrm{~m} / \mathrm{s}$ versus $205 \mathrm{~m} / \mathrm{s}$. If we take the shear wave at this site to be $5 \%$ faster than the surface wave then the $214 \mathrm{~m} / \mathrm{s}$ average converts to a shear wave velocity of $225 \mathrm{~m} / \mathrm{s}$. This is probably an average shear wave velocity of the upper 5 to $10 \mathrm{~m}$ since the surface wave is known to penetrate only 1 or 2 wavelengths. 


\section{CONCLUSIONS}

Four distinct seismic velocity layers are observed in the refraction data in the upper $10 \mathrm{~m}$. The top of the Pierre shale and the depth to saturated clay zone are corroborated by the trench and borehole data. A discontinuity of about $1.5 \mathrm{~m}$ occurs along the boundary between layer 2 and 3 at about station 160 . This discontinuity is not observed at the boundary between layers 1 and 2 or 3 and 4 .

\section{REFERENCES}

Mooney, Harold M., 1984, Handbook of Engineering Geophysics, Volume 1: Seismic, Bison Instruments Inc.

Aki, Keiiti, and Richards, Paul G., 1980, Quantitative Seismology, Theory and Methods volume 1, W.H. Freeman and Company, San Francisco, 557 p. 


\section{APPENDIX C}

Physical-properties data determined from field and laboratory measurements and a sample calculation of rebound volume change. 


\section{Volume Increase-Sample Calculation}

Example calculation of volume increases of voids $(\Delta P)$ and pore water $(\Delta W)$ that result from rebound in the weathered zone of the Pierre Shale. Calculations are based on a comparison of physical properties determined on trench samples and drill-hole cores sampled in the weathered and unweathered zones of the shale. Measurements necessary for determining, as nearly as possible, the natural state (NS) properties of the shale were made from extracted portions of minimally disturbed trench walls and cores. The calculation compares properties determined on a weathered trench sample taken at 2.56-m depth and on an unweathered core sample from 25.6-m depth. Determined properties from unweathered $(25.6 \mathrm{~m})$ and weathered $(2.56 \mathrm{~m})$ samples are as follows:

\begin{tabular}{|c|c|}
\hline $\begin{array}{l}\text { Unweathered sample } \\
25.6 \mathrm{~m} \\
\end{array}$ & $\begin{array}{r}\text { Weathered } \\
2.56 \mathrm{~m} \\
\end{array}$ \\
\hline 2.19 & 1.94 \\
\hline $\begin{array}{l}2.729 \\
14.23\end{array}$ & $\begin{array}{c}2.729 \\
18.77\end{array}$ \\
\hline $\begin{array}{l}14.23 \\
68.84\end{array}$ & $\begin{array}{l}18.71 \\
57.74\end{array}$ \\
\hline 31.16 & 36.41 \\
\hline 31.16 & 42.26 \\
\hline 100.0 & 86.1 \\
\hline
\end{tabular}

Bulk density, NS gr/cc

Grain density, dry $(\mathrm{gr} / \mathrm{cc})$

Moisture content (percent weight, NS)

Volume of solids (percent volume, NS)

Volume of pore water (percent volume, NS)

Porosity (percent volume of voids, NS)

Saturation (percent, NS)

Lithology and clay minerals remain essentially the same in both samples (Appendices $A$ and $C$ ). Expansion of the shale is primarily a result of the increased volume of void space allowing pore water to flow in. The unweathered clay matrix in the shale, when expanded, is assumed to maintain essentially the same mineralogy and volume of solid, but the pore volume and pore-fluid volume increase as an inverse function of depth.

(A) The increase of volume $\Delta S$ needed to accommodate total original volume of solids $\left(S_{\text {or }}\right)$ content $=$ original volume minus the new volume of solid $\left(S_{\text {or }}-S_{n}\right), \Delta S=68.84-57.74=11.10$ percent.

(B) The increased volume of voids $(\Delta P)$ needed to have a new porosity $\left(P_{n}\right)$ of 42.26 percent, $\Delta P=\Delta S \quad\left(1+P_{n} / 100-P_{n}\right)=19.22$ percent.

(C) The increased pore-water volume $(\Delta W)$, in addition to the original porewater volume $\left(W_{\text {or }}\right)$, needed to have a new pore-water volume $\left(W_{n}\right)$ of 36.41 percent, $\Delta W=W_{n}^{\text {or }}(100+19.22)-W_{\text {or }}=12.24$ percent. 
TABLE C-1.--Physical properties data determined from trench and core samples

\begin{tabular}{|c|c|c|c|c|c|c|c|c|c|}
\hline $\begin{array}{l}\text { Sample } \\
\text { Depth } \\
\text { (m) }\end{array}$ & $\begin{array}{l}\Delta W^{1} \\
\text { Pore } \\
\text { Water } \\
\text { Increase } \\
\text { Percent }\end{array}$ & $\begin{array}{c}\Delta P^{2} \\
\text { Volume } \\
\text { Increase } \\
\text { Percent }\end{array}$ & $\begin{array}{l}\text { Bulk } \\
\text { Density } \\
\text { GR/cC }\end{array}$ & $\begin{array}{c}\text { Moisture } \\
\text { Content } \\
\text { Percent }\end{array}$ & $\begin{array}{l}\text { Porosity } \\
\text { Percent }\end{array}$ & $\begin{array}{l}\text { Saturation } \\
\text { Percent }\end{array}$ & $\begin{array}{l}\text { Grain } \\
\text { Density } \\
\text { Gr/cc }\end{array}$ & $\begin{array}{l}\text { Atter } \\
\quad \text { Limi } \\
\text { Liquid } \\
\text { Limit }\end{array}$ & $\begin{array}{l}\text { rg } \\
\text { s } \\
\text { Plasti } \\
\text { Limit }\end{array}$ \\
\hline 2.56 & 12.24 & 19.22 & 1.94 & 18.77 & 42.26 & 86.1 & - & -- & -- \\
\hline 2.91 & 12.54 & 19.66 & 1.94 & 18.92 & 42.47 & 86.0 & 2.72 & -- & -- \\
\hline 2.91 & -- & -- & -- & -- & -- & --- & 2.75 & $\cdots$ & --- \\
\hline 4.00 & 3.24 & 7.11 & 2.08 & 15.48 & 35.73 & 89.9 & 2.70 & 49 & 22 \\
\hline 6.63 & 0.0 & 5.91 & 2.08 & 14.10 & 34.53 & 85.0 & -- & -- & -- \\
\hline 7.93 & 5.78 & 8.60 & 2.07 & 16.43 & 36.61 & 92.9 & 2.73 & -- & -- \\
\hline 10.21 & 10.08 & 13.41 & 2.02 & 18.92 & 39.30 & 92.5 & -- & --- & -- \\
\hline 13.11 & 13.11 & 6.87 & 2.09 & 16.84 & 36.31 & 96.9 & 2.74 & -- & -- \\
\hline 16.07 & 6.20 & 6.20 & 2.12 & 16.56 & 35.18 & 100.0 & 2.73 & -- & $\cdots$ \\
\hline 18.60 & 6.69 & 7.46 & 2.10 & 16.75 & 35.94 & 98.0 & - & -- & $\cdots$ \\
\hline 19.74 & 8.70 & 9.51 & 2.08 & 17.53 & 37.14 & 98.0 & 2.73 & -- & - \\
\hline 20.49 & 6.71 & 8.29 & 2.08 & 16.81 & 36.43 & 96.0 & -- & - & $\ldots$ \\
\hline 21.59 & 6.81 & 8.60 & 2.10 & 17.23 & 36.61 & 98.0 & -- & -- & -- \\
\hline 22.41 & 6.42 & 6.35 & 2.12 & 16.67 & 35.27 & 100.0 & 2.75 & $\ldots$ & $\ldots$ \\
\hline 24.01 & 2.67 & 2.67 & 2.16 & 15.24 & 32.95 & 100.0 & - & --- & $\cdots$ \\
\hline 25.61 & 0.0 & 0.0 & 2.19 & 14.23 & 31.16 & 100.0 & 2.72 & 41 & 19 \\
\hline 25.61 & -- & --- & -.- & -- & $\ldots$ & $\ldots$ & 2.72 & $\ldots$ & $\ldots$ \\
\hline
\end{tabular}

$1 \Delta W=$ Pore-water volume increase compared to unweathered sample at $25.61 \mathrm{~m}$. $2 \Delta P=$ Pore-volume increase compared to unweathered sample at $25.61 \mathrm{~m}$. 
Fig. C-1 Grain Size Analyses

A 25.91 meter depth

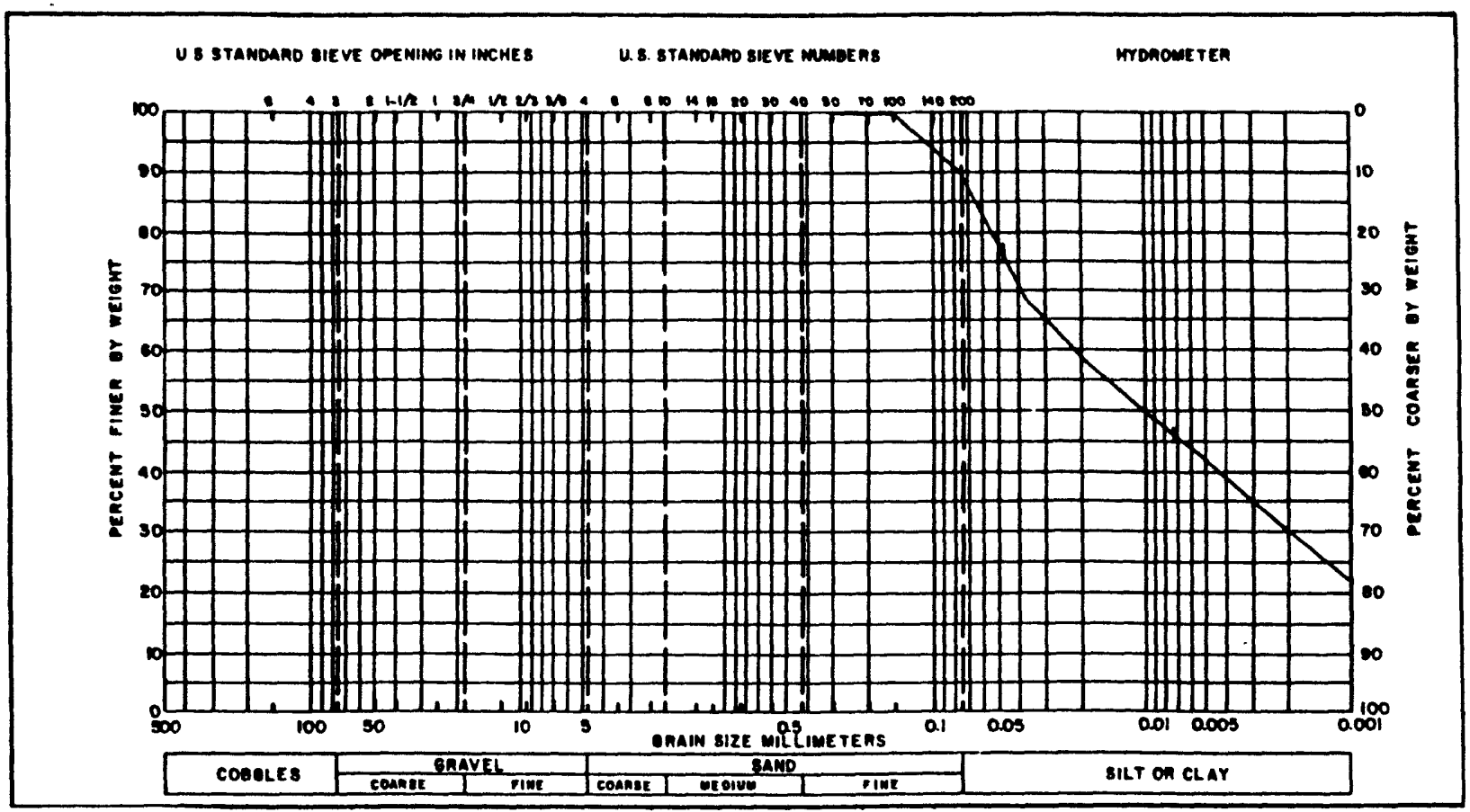

B 4.00 meter depth

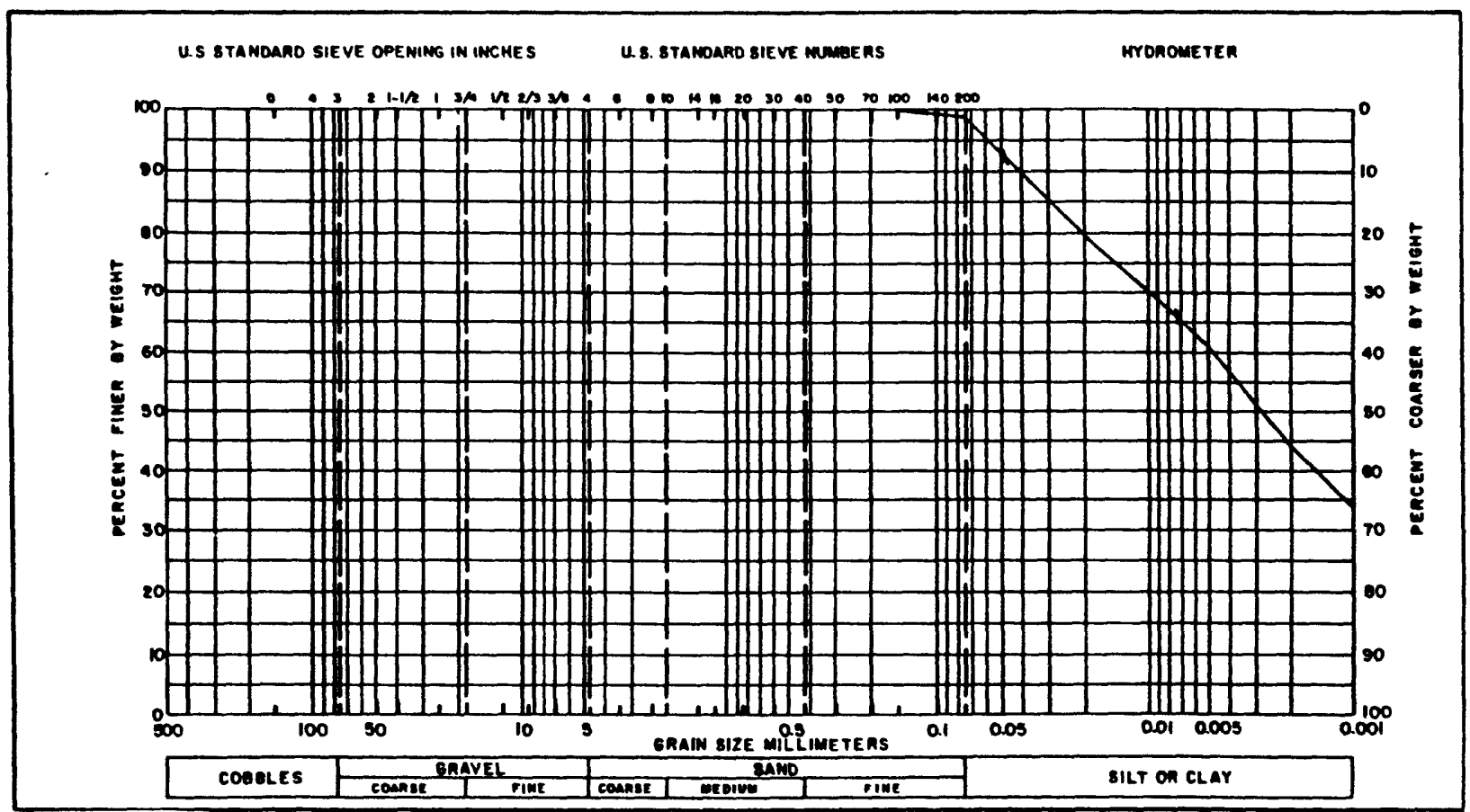




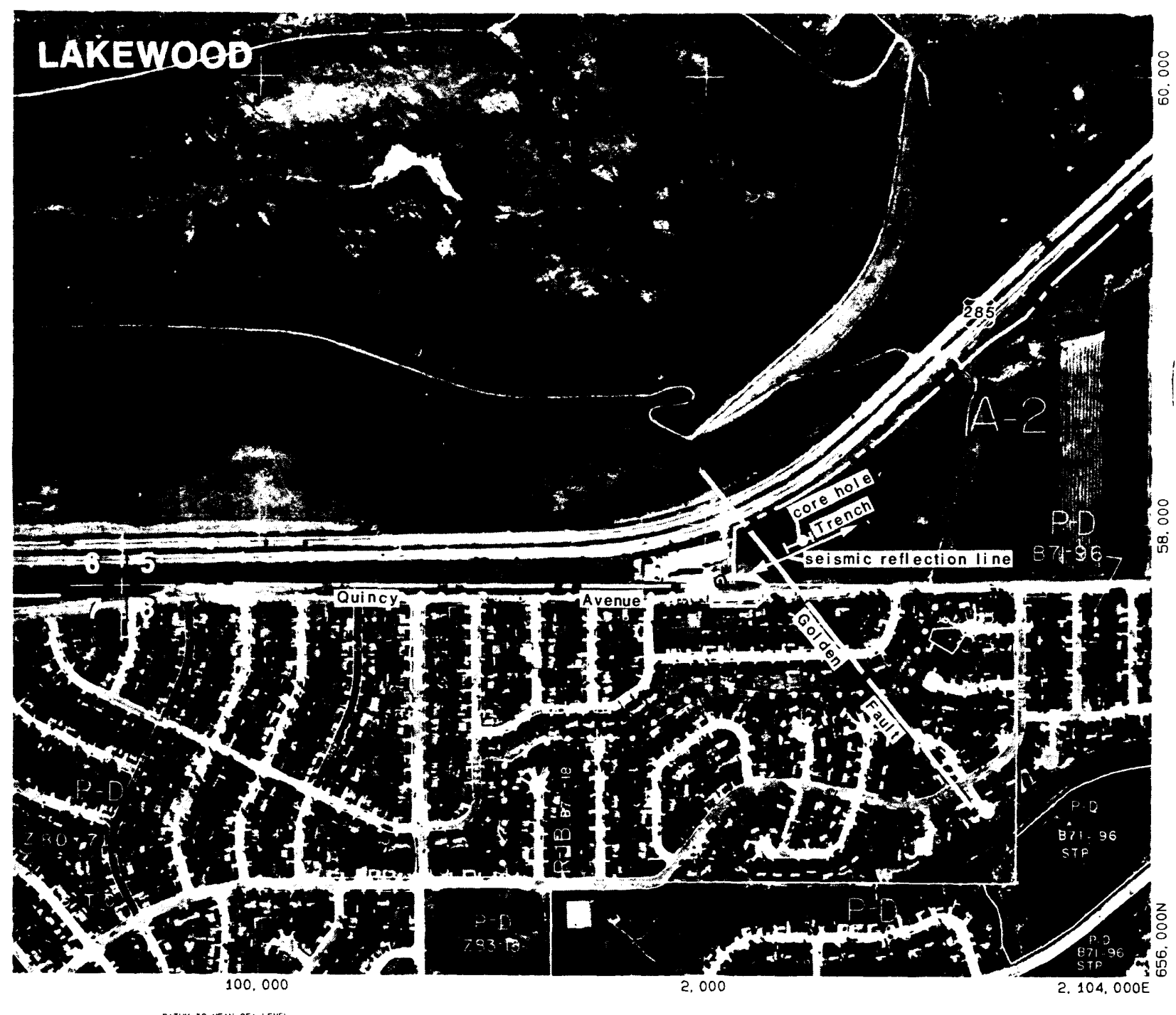

THIS MAP COMPLIES WITH NaTIONAL MaP ACCUAACY STANOABDS

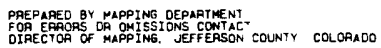

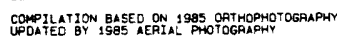

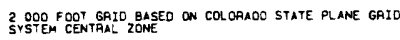

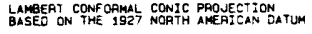

ORIGINAL PUBLICATION DATE MaY 1979

OATE OF LAST REVISION DECEMBEA 16 TP80

Map Number 56

TOWNSHIP 4-5 SOUTH. PANGE 69-70 WEST

OF THE GTH P.M.
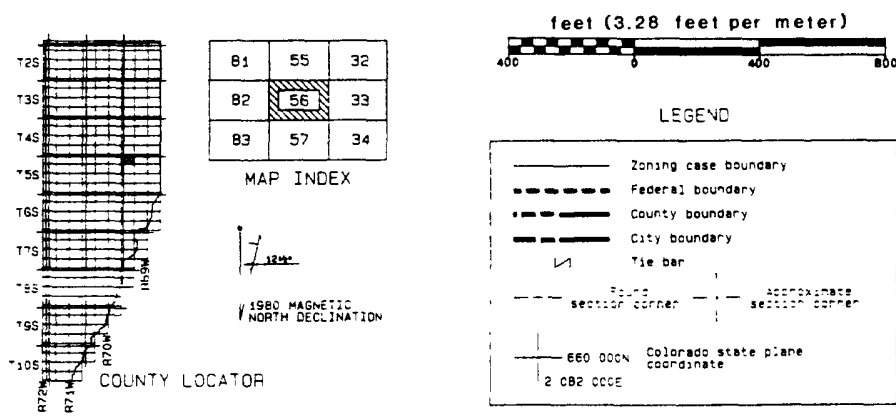

Plate 1-Map Showing Approximate Extension of the Golden Fault and Site Location for Trench, Core Hole and Seismic Reflection Line 


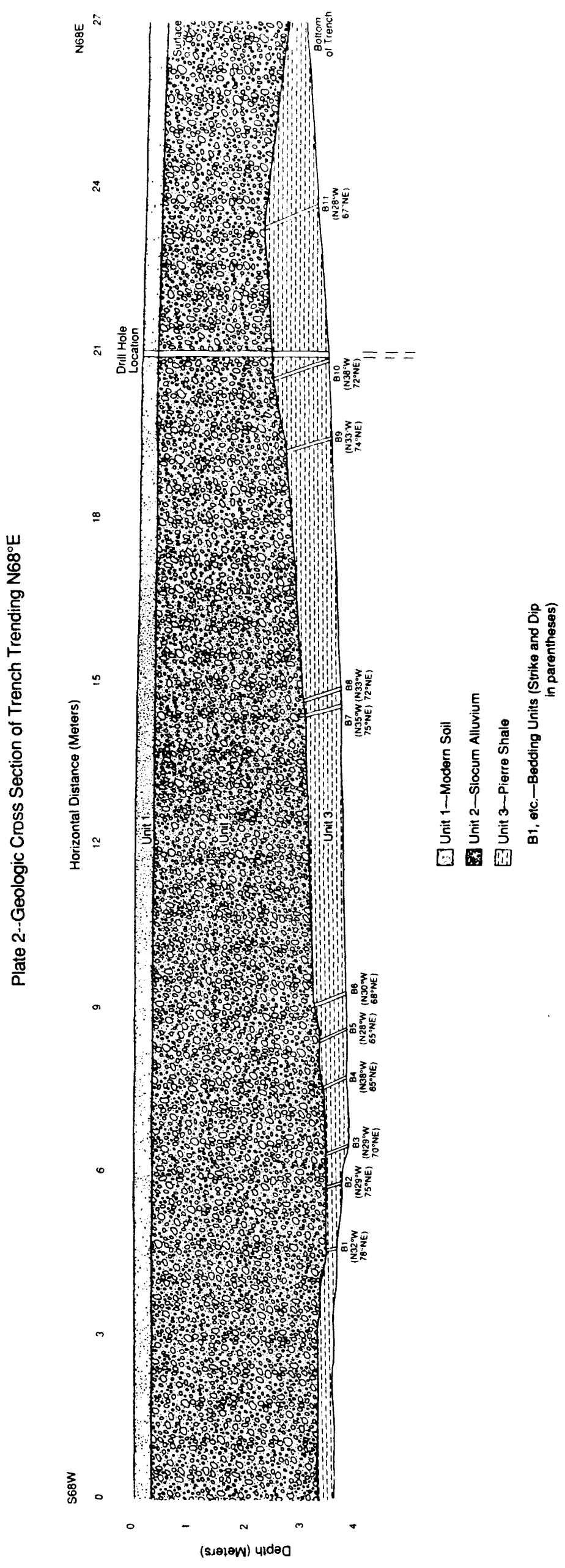




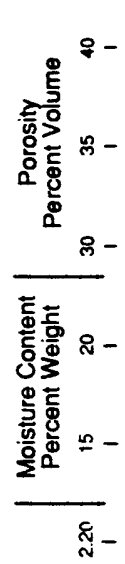

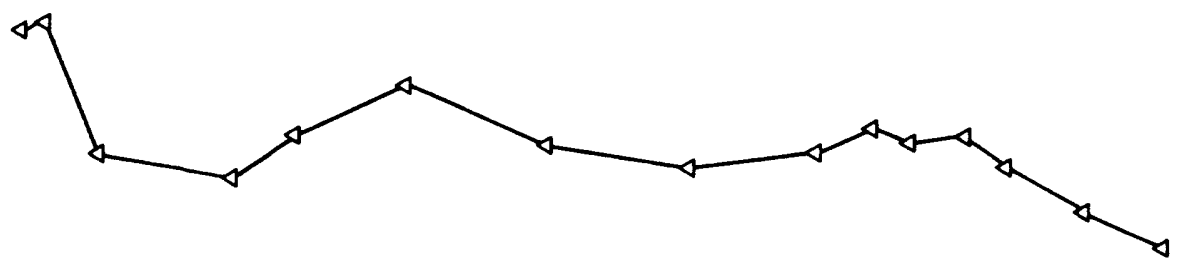

N

窟

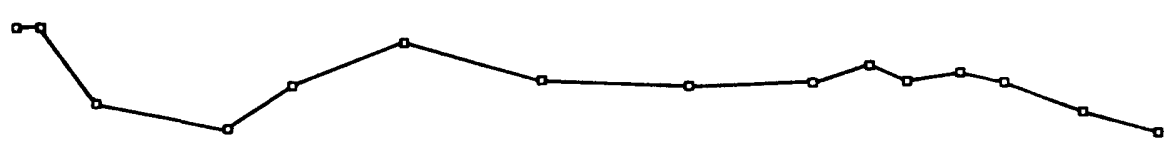

8 -

$\stackrel{2}{-}-$

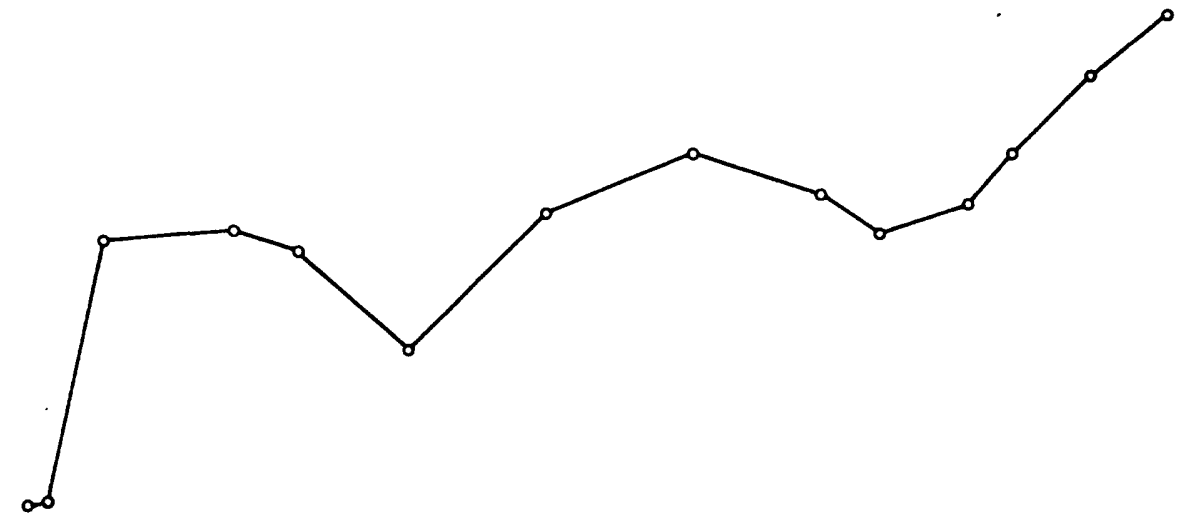

$\frac{8-}{8-}$
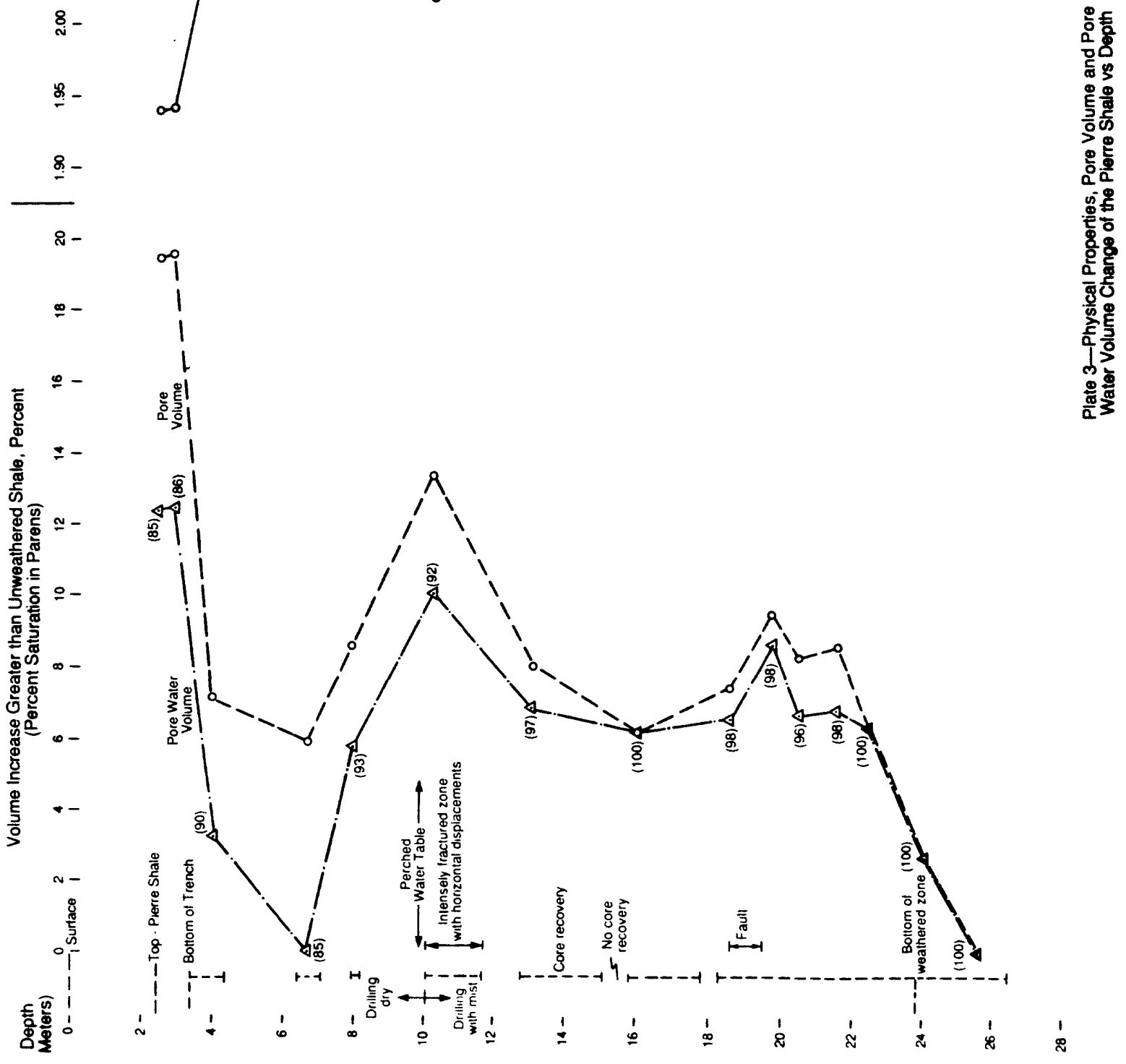

40 